\title{
Quasi-Fiscal Activities, Hidden Government Subsidies, and Fiscal Adjustment in Armenia
}

Lev Freinkman

Gohar Gyulumyan

Artak Kyurumyan

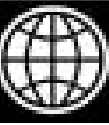


Copyright (C) 2003

The International Bank for Reconstruction and Development / The World Bank

1818 H Street, N.W.

Washington, D.C. 20433, U.S.A.

All rights reserved

Manufactured in the United States of America

First printing: September 2003

\section{3}

World Bank Working Papers are published to communicate the results of the Bank's work to the development community with the least possible delay. The typescript of this paper therefore has not been prepared in accordance with the procedures appropriate to journal printed texts, and the World Bank accepts no responsibility for errors. Some sources cited in this paper may be informal documents that are not readily available.

The findings, interpretations, and conclusions expressed in this paper are entirely those of the author(s) and do not necessarily reflect the views of the Board of Executive Directors of the World Bank or the governments they represent. The World Bank cannot guarantee the accuracy of the data included in this work. The boundaries, colors, denominations, and other information shown on any map in this work do not imply on the part of the World Bank any judgment of the legal status of any territory or the endorsement or acceptance of such boundaries.

The material in this publication is copyrighted. The World Bank encourages dissemination of its work and normally will grant permission for use.

Permission to photocopy items for internal or personal use, for the internal or personal use of specific clients, or for educational classroom use, is granted by the World Bank, provided that the appropriate fee is paid. Please contact the Copyright Clearance Center before photocopying items.

Copyright Clearance Center, Inc.

222 Rosewood Drive

Danvers, MA 01923, U.S.A.

Tel: 978-750-8400 • Fax: 978-750-4470.

For permission to reprint individual articles or chapters, please fax your request with complete information to the Republication Department, Copyright Clearance Center, fax 978-750-4470.

All other queries on rights and licenses should be addressed to the World Bank at the address above, or faxed to 202-522-2422.

ISBN: 0-8213-5604-6

eISBN: 0-8213-5605-4

ISSN: $1726-5878$

Lev Freinkman is Senior Economist in the Poverty Reduction and Economic Management Department of the Europe and Central Asia Region at the World Bank. Gohar Gyulumyan is Economist in the same department at the World Bank. Artak Kyurumyan is Consultant to the the World Bank.

\section{Library of Congress Cataloging-in-Publication Data}

Freinkman, Lev M.

Quasi-fiscal activities, hidden government subsidies, and fiscal adjustment in Armenia/

Lev Freinkman, Gohar Gyulumyan, Artak Kyurumyan.

p. cm.-- (World Bank working paper; no. 16)

Includes bibliographical references.

ISBN 0-8213-5604-6

1. Finance, Public--Armenia (Republic) 2. Fiscal policy--Armenia (Republic) 3. Budget deficits--Armenia (Republic) I. Gyulumyan, Gohar. II. Kyurumyan, Artak. III. Title. IV. Series. 


\section{TABle of Contents}

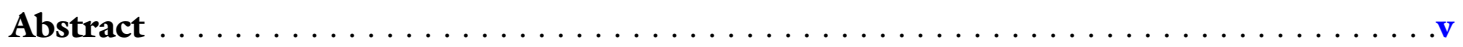

Acknowledgments $\ldots \ldots \ldots \ldots \ldots \ldots \ldots \ldots \ldots \ldots \ldots \ldots \ldots \ldots$ vii

Acronyms and Abbreviations $\ldots \ldots \ldots \ldots \ldots \ldots \ldots \ldots \ldots \ldots \ldots \ldots \ldots \ldots \ldots \ldots$

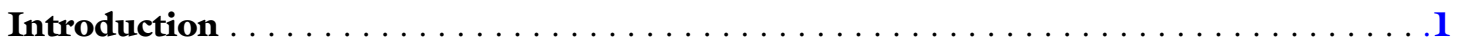

Chapter 1. Traditional and Alternative Approaches to the Evaluation of

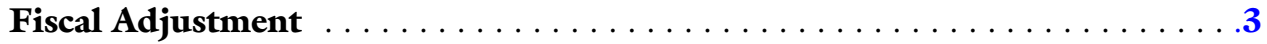

Chapter 2. Quasi-Fiscal Activities in the FSU Countries $\ldots \ldots \ldots \ldots \ldots \ldots \ldots \ldots \ldots$

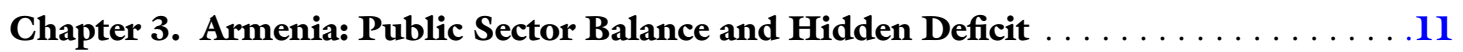

Chapter 4. Hidden Budget Subsidies, Quasi-Fiscal Subsidies and Contingent

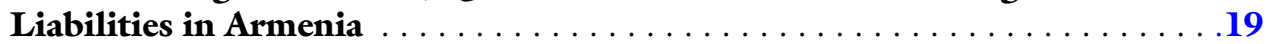

Chapter 5. Financing of Hidden Deficit and Ultimate Recipients of Quasi-Fiscal Subsidies . . . . . . . . . . . . . . . . . . . . 29

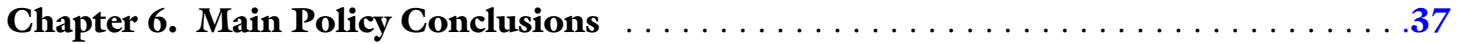

\section{ANNEXES}

Annex A. External borrowing by Government to support of operations

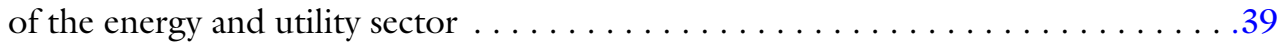

Annex B. Main Annual Subsidy Flows in the Economy, 1996-2001, million Dram . . . . . .41

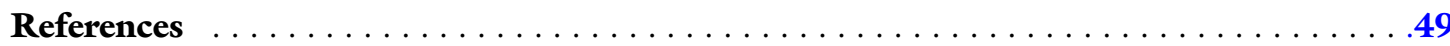

\section{TABLES}

Table 1. Armenia: Pre-Transition Price Distortions and Price Adjustment

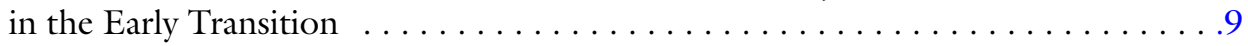

Table 2. Net Present Value of External Debt, in Percent, 2000 and 2002 . . . . . . . 12

Table 3. General Government's Budget Deficits in the Ex-USSR States, Cash . . . . . . . . 14

Table 4. Armenia: Actuarial, Conventional, and Hidden Deficit, 1995-2001 . . . . . . 15

Table 5. Budget Subsidies and Direct Budget Credits to Large SOEs . . . . . . . . . . . 21

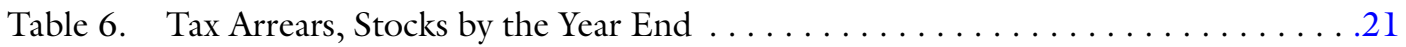

Table 7. Subsidization Through the Gas-for-Equity Privatization $\ldots \ldots \ldots \ldots \ldots \ldots 22$

Table 8. Government External Borrowing to Support Operations

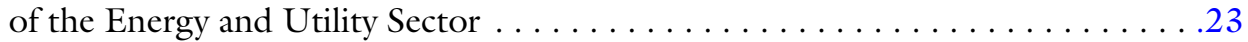

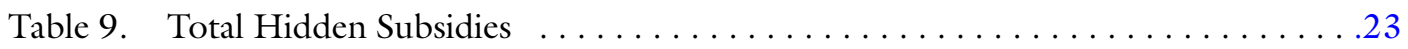

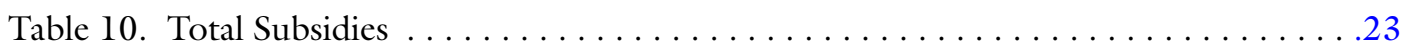

Table 11. Electricity Tariffs in Selected Economies in Transition in 2000, Without VAT . . 25

Table 12. Customers' Non-payments to Main Utilities $\ldots \ldots \ldots \ldots \ldots \ldots \ldots \ldots$

Table 13. Government Guarantees Issued for Banking Credits Granted to

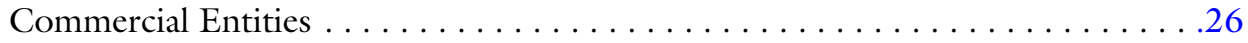

Table 14. Outstanding Banking Credits to the E\&U Sector in 1998-2001 . . . . . . . .27

Table 15. The Annual Average Under-financing in the Energy and

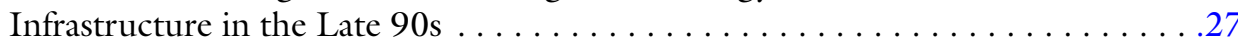


Table 16. Armenia. Inter-sectoral Flows of Subsidies, 1999 . . . . . . . . . . . . . . .30

Table 17. Recipients and Donors of Quasi-Fiscal Subsidies in Armenia . . . . . . . . . . .32

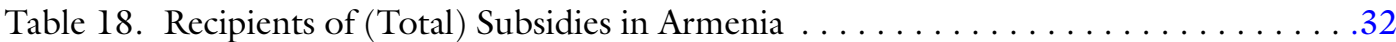

Table 19. Financing of Subsidies Provided by the Energy Sector . . . . . . . . . . . 35

Annex A. External Borrowing by the Government to Support Operations of the

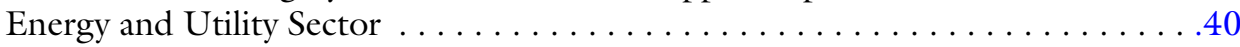

Annex B. Main Annual Subsidy Flows in the Economy, 1996-2001 . . . . . . . . . . . . .42

\section{FIGURES}

Figure 1. Real Exchange Rate Developments in Selected CIS Countries . . . . . . . . . .12

Figure 2. Average GDP Growth in Selected CIS Countries, 1997-2001 . . . . . . . . . . 12

Figure 3. Average Annual Inflation in Selected CIS Countries, 1997-2001 . . . . . . . . 13

Figure 4. Armenia: Hidden Deficit as Percent of GDP, 1995-2001 . . . . . . . . . . . 16

Figure 5. Armenia: Composition of Actuarial Deficit $\ldots \ldots \ldots \ldots \ldots \ldots \ldots \ldots \ldots$

Figure 6. Armenia: Accrual and Actuarial Deficits $\ldots \ldots \ldots \ldots \ldots \ldots \ldots \ldots \ldots \ldots$

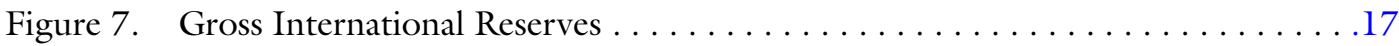

Figure 8. Moldova: Fiscal Adjustment, $1995-2000 \ldots \ldots \ldots \ldots \ldots \ldots \ldots \ldots$

Figure 9. Budgeted Subsidies, Hidden Subsidies, and Quasi-Fiscal Subsidies . . . . . . . 24

Figure 10. Fiscal and Quasi-Fiscal Financing of Quasi-Fiscal Subsidies

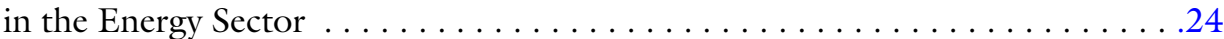

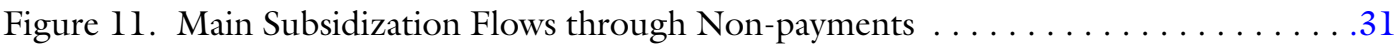

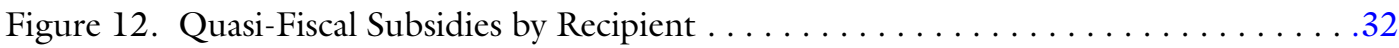

Figure 13. Quasi-Fiscal Subsidies by Source of Financing $\ldots \ldots \ldots \ldots \ldots \ldots \ldots \ldots$

Figure 14. Quasi-Fiscal Subsidies to Population as a Share of Total QFS . . . . . . . . 33

Figure 15. Quasi-Fiscal Subsidies to Population and Budget Expenditures on

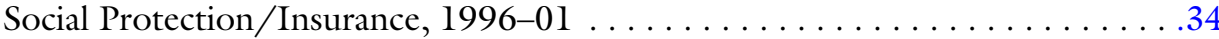

Figure 16. Budgeted, Hidden, and Quasi-Fiscal Subsidies to the Enterprise Sector . . . . . .34 
$\mathrm{T}$

his paper aims to develop a detailed analysis of quasi-fiscal deficits and subsidies, and their impact on Armenia's fiscal performance in the second part of the 1990s. Based on the flow-offunds approach, we estimate the magnitude of the quasi-fiscal deficits and the incidence of quasifiscal subsidies in Armenia, as well as identify main recipients and sources of quasi-fiscal financing. The principal finding of the paper is that while quasi-fiscal deficits in Armenia remain considerable, their recent decline has been a major contributing factor to Armenia's fiscal adjustment. The paper also shows that households remain a major ultimate recipient of quasi-fiscal subsidies. Thus, the main distortive impact of quasi-fiscal subsidies is on social policy and equity, rather than on enterprise restructuring and private sector performance. Still, the current level of public sector deficit in Armenia remains too high, which requires an additional adjustment effort. The paper suggests that to make fiscal adjustment sustainable a further strengthening of financial control, accounting and reporting in the public sector is needed, including through better Government monitoring of debts and other liabilities accumulated by the large state enterprises and phasing out the phenomenon of implicit (hidden subsidies), such as debt-for-equity swaps. The proposed approach to the analysis of quasi-fiscal deficits and subsidies, based on estimates of accumulated debts in the public sector and its main parts, seems to be fully applicable to other economies in transition, especially to those low-income CIS countries, which are heavily dependent on energy imports. 

A $\mathrm{n}$ earlier draft of this paper was prepared for the Conference "Armenia: Recent Economic Trends and Growth Prospects," organized by the Armenian International Policy Research Group on January 25, 2003 in Washington, D.C.

The views in the paper are those of the authors, and should not be attributed to the World Bank. The authors are grateful to Azamat Abdymomunov, Ani Balabanyan, Vladimir Drebentsov, Artsvi Khachatryan, Rendall Maringer, Gayane Minasyan, Alexander Morozov, Brian Pinto, Carolina Revenco, Gevorg Sargsyan, Brian Steven Smith, Eka Vashakmadze and Ann-Margret Westin for comments and help with data. 



\section{ACRONYmS AND AbBreViations}

$\begin{array}{ll}\text { CBA } & \text { Central Bank of Armenia } \\ \text { CEE } & \text { Central and Eastern European } \\ \text { CIS } & \text { Centrally-planned Independent States } \\ \text { CL } & \text { Contingent Liabilities } \\ \text { E\&U } & \text { Energy and Utility (sector) } \\ \text { EBF } & \text { Extra-Budgetary Funds } \\ \text { FSU } & \text { Former Soviet Union } \\ \text { IMF } & \text { International Monetary Fund } \\ \text { PSB } & \text { Public Sector Balance } \\ \text { QF } & \text { Quasi-Fiscal } \\ \text { QFS } & \text { Quasi-Fiscal Subsidies } \\ \text { SOE } & \text { State-Owned Enterprises }\end{array}$



$\mathrm{T}$ his paper aims to develop a detailed analysis of quasi-fiscal deficits and subsidies, and their impact on Armenia's fiscal performance in the second part of the 1990s. Based on the flow-offunds approach, we estimate the magnitude of the quasi-fiscal deficits and the incidence of quasifiscal subsidies in Armenia, as well as identify the main recipients and donors of quasi-fiscal financing. The main finding of the paper is that while quasi-fiscal deficits in Armenia remain considerable, their recent decline has been the main source of fiscal adjustment in Armenia to date. The paper also shows that the population remains a major ultimate recipient of quasi-fiscal subsidies. Thus, the main distortive impact of quasi-fiscal subsidies is on social policy, not on enterprise restructuring and private sector performance.

The paper is organized as follows. The first chapter introduces an analytical framework for our analysis of quasi-fiscal deficits. This is followed by a discussion of specific features of quasi-fiscal financing in transition economies. The third chapter provides estimates of Armenia's actuarial and hidden deficits in the second part of the 1990s and shows that, in comparison to some of the other CIS countries, its hidden deficits were modest. The fourth chapter presents a comprehensive picture of subsidization in Armenia, including hidden and quasi-fiscal subsidies that were a primary cause of the hidden deficit. The final chapter brings more detailed analysis of quasi-fiscal subsidies in Armenia by showing their ultimate sources and main beneficiaries. 



\section{TRADITIONAL AND Alternative Approaches TO THE EVAlUation OF Fiscal ADJUSTMENT}

The traditional approach to assessment and analysis of fiscal adjustment is based on the concept of government deficit, which is usually defined as an excess of expenditure over income (IMF 1995). The expenditure/income approach has three well-known limitations:

(1) it covers only the items that are included in the government budget or balance sheet and therefore is heavily dependent upon the comprehensiveness of existing budget coverage; ${ }^{1}$

(2) it is focused on cash-based transactions and usually misses most non-cash Government operations;

(3) it has a limited time horizon, since it is highly unusual to consider budget deficit estimates for periods that are longer than one year.

Thus, in an environment in which fiscal accounts remain underdeveloped, conventional measures of the fiscal deficit could generate a distorted picture of the Government finances. Therefore, they are an unreliable tool for monitoring and evaluating basic fiscal developments. Specifically, they may not distinguish well enough between a genuine fiscal adjustment and one that brings shortterm improvements but undermines longer-term fiscal sustainability. Reduction in fiscal deficit does not necessarily imply a genuine fiscal adjustment, which has to meet tests of sustainability and efficiency (Selowsky 1998).

As shown by Easterly (1998), when an outside agent forces the government to reduce conventional indicators for its deficits and debts, it may trigger a sub-optimal policy response in which the government substitutes true adjustment with excessive reductions in assets and/or increases in implicit liabilities, for example, by privatizing public property, disinvesting, accumulating hidden debts, under-financing critical maintenance spending, extracting advance payments of taxes, borrowing from pension funds and other quasi-public entities, etc.

1. It also does not reflect capital gains/losses of the Government, which often becomes an important component of the overall debt dynamics. 
Easterly argues that a government's net worth (net present value of its assets and liabilities) is a more relevant concept for evaluation of government inter-temporal behavior. Rational governments should be much more concerned with longer-term optimization of their net worth than with annual improvements in the deficit indicators. More accurately, within a rational fiscal strategy, improvements in current balances have to be complemented by growth in net worth. If the net worth remains unchanged, then the true size of the government deficit does not decline. Simple shifts in allocations among assets and liabilities (both explicit and implicit), although they may improve conventional deficit indicators, produce an illusory fiscal adjustment.

Unlike the conventional indicators of fiscal deficit, which represent a flow concept, an alternative-actuarial deficit-is defined through stock variables as the change in the total stock of government liabilities, that is, the entire stock of public debt and the money base (Karas and Mishra 2001). Thus, it is defined as:

$$
\mathrm{D}_{t}^{a}=\left(\mathrm{B}_{t}-\mathrm{B}_{t-1}\right)+\left(\mathrm{M}_{t}-\mathrm{M}_{t-1}\right)
$$

where $\mathrm{D}_{t}^{a}$ is the actuarial budget deficit in period $t ; \mathrm{B}_{\mathrm{t}}$ is the stock of the public debt; and $\mathrm{M}_{t}$ is the base money. The difference between the actuarial and the conventional deficits is called the hidden deficit.

Karas and Mishra computed conventional, actuarial, and hidden deficits for 32 countries and concluded that there is a close link between the level of both hidden and actuarial deficits and core macroeconomic outcomes, specifically the incidence of currency crises. ${ }^{2}$ They argue that a currency crisis may be triggered by an increase in the hidden deficit through accumulation of government realized contingent liabilities, when markets perceive that such accumulation is likely to lead to an unsustainable expansion in conventional deficits. The hidden deficits may also derive from capital losses associated with currency risks of government debt portfolio.

Hidden government deficits emerge as a result of various public sector operations that are not reflected (partially or entirely) in the regular government budget. In this paper we look only at quasi-fiscal activities (QFA) that relate to subsidization-those that could be described as a net transfer of public resources to the private sector (enterprises and households) through non-budget channels. This is the most common type of QFAs. At the same time, this paper does not consider other types of quasi-fiscal activities, for instance, quasi-fiscal taxation. ${ }^{3}$ Also, we do not look into the CIS traditional quasi-fiscal instrument of sectoral extra-budgetary funds (EBFs). While EBFs were a major source of quasi-fiscal subsidization in the early 1990s (Delyagin and Freinkman 1993), their incidence has declined considerably. In most cases, including Armenia, EBF spending now remains within the government sector as an additional (and non-transparent) source of financing core government services such as tax administration, but not of subsidies.

Governments in most countries are to some extent engaged in economic activities that go beyond the traditional definition of public sector services and of conventional fiscal policy instruments. In particular, they try to protect, support and subsidize domestic industries to make them more competitive and financially viable, and often they do it through implicit subsidization, such as various tax benefit schemes. However, governments in developed countries tend to generate and disclose explicit cost estimates of such implicit subsidies, and, more importantly, these policies usually bring only limited accumulation of contingent liabilities. Developing and transition economies are quite different: the incidence of QFAs is higher, their fiscal implications often remain non-

2. According to their calculations, the correlation between number of currency crises and actuarial deficit is 0.55 , while with conventional deficit it is only 0.15 .

3. Quasi-fiscal taxation has been almost entirely phased-out in most CIS countries by the late 1990s, while it was quite significant early in transition, especially during the high inflation period. For instance, Easterly and Viera da Cunha (1993) estimate that in 1992 the Russian private sector paid about 30 percent of GDP in the inflation tax. Other major quasi-fiscal taxes on enterprises included taxation on exporters through mandatory sales of export proceeds at non-market exchange rates, and forced direct financing by enterprises of core social services. 
quantified, and building contingent liabilities to finance QFAs is rather common. Karas and Mishra (2001) estimate that the developed countries in their sample had annual hidden deficits that ranged from -0.7 percent of GDP to 1.6 percent, while in 16 out of 25 developing countries the average hidden deficit (or surplus) exceeded 1.5 percent of GDP per year. Polachkova Brixi, Schick and Zlaoui (2002) analyzed the fiscal adjustment effort by several Central European economies, and demonstrated that the results of assessment of fiscal adjustment undertaken by these countries would change substantially if the assessment covers quasi-fiscal government obligations in a systematic way.

IMF Manual (2001) identifies three core types of quasi-fiscal activities, associated respectively with the operations of the financial sector, exchange rate system, and commercial enterprises. Common examples of quasi-fiscal subsidies include multiple exchange rate regimes, direct lending at below-market rates by the central bank and commercial banks, provision of goods and services by public enterprises at prices that are set below the market (or cost recovery) levels, etc. The primary negative effects of such QFAs relate to resource misallocation and non-transparency. They are usually "bad subsidies" that serve special interest groups and are not subject to Parliamentary scrutiny. As such they tend to undermine both the effectiveness and the integrity of the fiscal policy and budget process. QFAs regularly lead to large-scale bailout operations to support companies and banks that earlier have been a source of hidden deficit financing. This brings serious macroeconomic consequences as well as a moral hazard, since bailouts "legitimize" soft budget constraints for recipients of quasi-fiscal subsidies. ${ }^{4}$

Thus, it is important to distinguish between two sides of quasi-fiscal activities: (a) mechanisms of non-transparent subsidization of the private sector, including households (that is, how are resources transferred?); and (b) financing of these subsidies (who is paying for this resource transfer and how?).

Moreover, the problem of quasi-fiscal deficits and subsidies has two interrelated and equally important dimensions that relate respectively to macroeconomic and enterprise sector performance. Accumulated experience with transition since 1990 suggests that a dramatic reduction in total subsidies (budgeted and non-budgeted) is a critical prerequisite for both macroeconomic stabilization and enterprise restructuring, and at the same time it has a major impact on the credibility of the entire reform process (Pinto et al. 2000a, 2000b).

In this paper, we are aiming for a comprehensive framework to analyze issues of quasi-fiscal financing that include three inter-related parts:

(i) overall impact of quasi-fiscal subsidies on public financing, that is, the size of hidden deficit in the public sector (Chapter 2);

(ii) main channels of quasi-fiscal resource transfer to the enterprise sector and households (Chapter 3); and

(iii) how these quasi-fiscal subsidies (and related hidden deficit) were financed (Chapter 4 ).

4. Polackova-Brixi, Ghazem and Islam (2001) describe how QFAs in the Czech Republic became a source of conventional fiscal problems. This happened due to excessive expansion of explicit and implicit government guarantees for commercial credits as well as because of high incidence of off-budget spending by de facto budget institutions. Overall, the actual improvement in fiscal balances in the Czech Republic was overstated by some $3-4$ percent annually in the mid-1990s. 

Chapter 2

\title{
QuAsi-Fiscal ACtivities IN THE FSU COUNTRIES
}

\begin{abstract}
$\mathrm{C}$ ompared to most developing countries, former socialist economies in Central and Eastern Europe (CEE), and especially those in the FSU, started their market reforms with a much higher burden of QFAs. This derived from two factors: (1) SOEs in these countries have been a major source of financing and provision of either free or highly subsidized public services; ${ }^{5}$ and (2) consumers in these economies have been accustomed to high (relative to their post-socialist income levels) consumption of energy and utility services, which were delivered at low prices and in the absence of reliable mechanisms to enforce payments for received services. ${ }^{6}$ As a result, most QFAs in transition economies are associated with the activities of SOEs in the energy sector, while elsewhere in the developing world, QFAs were traditionally generated by financial sector entities (IMF 1995, pp.17-18). The above mentioned structural peculiarities of the CIS economies were further aggravated by a typical (for transition economies) combination of weak accounting and reporting practices and pressures for fiscal adjustments, which created additional risks of expansion of quasi-fiscal activities (Polachkova Brixi and Schick 2002).

These peculiarities of CEE economies proved to be a major stumbling block for the reform process in transition in general, and especially in the CIS economies, because these were the most isolated from the impact of world energy prices. Phasing out QFAs has been rather slow in most CIS countries, and its progress has broadly followed the path (with all its ups and downs) of macroeconomic stabilization in the region. The transfer of social services from enterprises to municipalities has been difficult because of the traditional weakness of municipal governments and slow fiscal decentralization. As a result, governments were forced to tolerate QFAs and did not impose hard budget constraints on SOEs that continued to finance energy subsidies and social services.
\end{abstract}

5. Freinkman and Starodubrovskaya (1996) provide a detailed account of public services provided by Russian SOEs in the first part of the 1990s and estimate that the value of these services amounted to 3-4 percent of GDP or about 20 percent of their gross wage bill.

6. For instance, in Russia and several other countries, national Civil Codes contain provisions that seriously erode the right of the supplier to disconnect customers for non-payment. 
The introduction of fiscal discipline in the energy sector has been among the most challenging reforms in transition. Since very early in transition, enterprises and households in the region were not able to afford the traditional level of energy consumption at world prices, while governments were initially reluctant and later slow to raise domestic energy prices and to introduce an aggressive policy of cutting off non-paying energy customers. This happened partly due to real political concerns about the social implications of dramatically higher energy prices and anticipated mass bankruptcies, and partly due to well-organized pressure from domestic interest groups. As a result, energy-related subsidies became the main channel of subsidization in CIS economies, which in turn made them a primary source of soft budget constraint for the enterprise sector, as well as a significant additional source of fiscal and macroeconomic risks.

While a high incidence of energy-related subsidies has become a universal phenomenon in the CIS since the early 1990s, their fiscal and macroeconomic consequences in a specific country were different depending upon access to energy resources. Energy-exporting countries (Russia, Kazakhstan, Azerbaijan) had a possibility for delaying energy sector reforms and financing energy subsidies through implicit taxation of their energy producers. Energy-dependent countries, especially those that do not have access to major transit pipelines (Armenia, Georgia, Kyrgyz Republic), were quickly forced to import energy at prices close to those of world markets, and thus were required to make difficult choices about the sources of financing of the remaining subsidies. Access to transit oil and gas pipelines (in Ukraine and Moldova) helped to delay shocks by providing access to significant amounts of de facto free energy. However, stealing gas from the Russian pipelines proved to be an unsustainable strategy and made the ultimate adjustment in these countries even more painful. ${ }^{7}$

The case of Russia provides a good illustration of the typical adjustment pattern in an energyabundant CIS economy. Until the 1998 crisis, Russian federal and sub-national governments were excessively protective of "socially important" enterprises from bankruptcy and downsizing, and uninterrupted access to energy was a major channel of subsidization. In 1995-97, annual hidden and untargeted subsidies, provided through systematic nonpayment of both taxes and energy supply, amounted to 7-10 percent of GDP (Pinto et al. 2000b). Simultaneously, as liberalization and stabilization in Russia progressed, implicit taxes on energy exporters, which earlier helped to finance these subsidies, disappeared. Moreover, by 1997, the main energy monopolies became capable of transferring practically the entire cost of hidden subsidies to the consolidated government budget. This was achieved by accumulating tax arrears ${ }^{8}$ and winning considerable tax benefits, especially with respect to export sales. The Russian Government was forced to expand its external and domestic borrowing to cover the widening fiscal gap, which eventually became a core trigger for the 1998 crisis. In turn, imposition of much stronger budget constraints on both energy consumers and energy producers became a major component of Russian fiscal recovery after 1998 (Alam and Sundberg 2002).

In Azerbaijan, under-pricing of energy and non-payment to energy suppliers have been the main types of quasi-fiscal subsidies (Petri et al. 2002). The total amount of quasi-fiscal subsidies provided to domestic end-consumers through sales that were priced below the opportunity costs amounted to 7 percent of GDP in 1999. The main non-payers in the economy have been households, which on average pay only 10 percent of their energy bills.

In energy dependent countries in the CIS, the adjustment path was different. Hikes in energy prices (Table 1) led to a painful adjustment in energy consumption, which, however, was much smaller than the decline in incomes of both local consumers and governments. ${ }^{9}$ As a result, the

7. It is estimated that the value of transit gas stolen in Ukraine by May 2000 reached $\$ 1$ billion or 3 percent of Ukraine's 2000 GDP (Petri et al. 2002, p. 13)

8. The outstanding stock of unpaid taxes by the energy sector exceeded 3.5 percent of GDP at the end of 1997, despite several major offset exercises undertaken by the Government in the mid-1990s.

9. In Armenia, for instance, electricity consumption declined 2.9 times between 1991 and 1995, while non-agricultural GDP declined by four times. 


\begin{tabular}{|c|c|c|}
\hline & $\begin{array}{l}\text { Price ratios between world } \\
\text { and pre-transition (1988) } \\
\text { domestic prices, by sector }\end{array}$ & $\begin{array}{l}\text { Relative price growth } \\
\text { by sector in } 1988-94 \text {, actua }\end{array}$ \\
\hline Total Industry, weighted average & 1.00 & 1.00 \\
\hline o/w: Manufacturing & 0.95 & n.a. \\
\hline Energy & 2.48 & 3.52 \\
\hline Non-ferrous metallurgy & 2.10 & 3.56 \\
\hline Chemical and petrochemical & 1.24 & 4.11 \\
\hline Machinery and metal processing & 1.56 & 0.76 \\
\hline Forestry and wood processing & n.a. & 2.46 \\
\hline Construction materials industry & n.a. & 2.33 \\
\hline Light industry & 0.54 & 0.58 \\
\hline Food industry & 0.52 & 1.00 \\
\hline Other industries & 1.30 & n.a. \\
\hline
\end{tabular}

Source: Estimates by Vahram Avanessian and the National Statistical Service.

remaining energy subsidies, still considerable, have been financed primarily by accumulating external arrears to energy suppliers and by under-financing of sectoral maintenance. Because the main energy companies in the energy-importing countries have remained state-owned, the arrears were eventually transformed into government-to-government debts. Russia and Turkmenistan-the primary energy exporters in the CIS-became major creditors to other FSU countries.

In Ukraine, for instance, quasi-fiscal subsidies originating in the gas sector amounted to 5.6 percent of GDP in 2000 and were mostly financed through accumulation of arrears to Russian gas suppliers. Arrears by energy consumers amounted to about three-fourths of total subsidies. Households received about a half of this amount, including through massive non-payments for gas received and electricity (Petri et. al. 2002).

Many CIS economies' high dependence on energy imports and the inability to reduce it in the short term proved to be a major feature in the local political economy of reforms, affecting their overall reform path. These states became quite vulnerable to real and potential energy pressures, associated with possible cuts of energy supplies for non-payments. Moreover, powerful interest groups have emerged that became major beneficiaries of remaining energy subsidies and natural supporters of the status quo.

Despite programs of massive international assistance, launched in most of these states between 1991 and 1999, external debts of the low-income CIS countries increased from close to zero to unsustainable levels (World Bank 2001a). ${ }^{10}$ Quasi-fiscal (hidden) government deficits, especially those that were related to the energy sector, were the single major factor responsible for such unsustainable debt dynamics. And the debts that have their roots in the energy sector have, as a rule, become the most expensive part of the debt burden. Therefore, energy sector reform has migrated to the center of the overall reform agenda in the CIS because of its critical linkages with fiscal sustainability, enterprise restructuring, and reforms in social protection.

10. Several donors' projects in that period were explicitly designed to facilitate restructuring and/or repayment of energy-related external debts. 

Chapter 3

\section{Armenia: Public Sector BALANCE AND Hidden Deficit}

C

ompared to other low-income and energy-dependent CIS economies, Armenia has shown somewhat stronger macroeconomic performance in the second part of the 1990s. ${ }^{11}$ This

has been most noticeable with respect to exchange rate and public debt developments. Armenia was the only country in the group that managed to avoid a destructive currency devaluation following the 1998 Russia crisis (Figure 1). Its external debt remained manageable through the entire period and, moreover, Armenia's debt profile did improve considerably in 2000-02 (Table 2). At the same time, Armenia had a higher average growth rate and lower inflation during the period (Figures 2 and 3 ). In addition, its public finance system has been less affected by such common regional problems as barter, cash substitutes, pension and other government arrears.

This comes somewhat as a surprise because Armenia's stronger macroeconomic outcomes could not be explained or linked to any significant differences in its budget performance. Conventional estimates for Armenia's budget deficit were in fact higher than those for many of its comparators during the period (for example, Georgia, Tajikistan, Ukraine), including the years before the Russia crisis (Table 3).

As argued in the rest of the paper, the primary explanation for this would be the fact that in Armenia hidden off-budget deficits were much lower than in other low-income economies in the CIS. Despite its persistent problems in the energy and utility sectors, Armenia has been more successful than the average economy in the group in reducing overall quasi-fiscal subsidies and putting a relatively large part of the rest into the regular budget. This proved to be a critical contribution to improvements in macroeconomic trends. The main finding of this paper is that a main source of fiscal adjustment in Armenia to date was indeed the reduced quasi-fiscal deficits.

Table 4 presents estimates for the conventional, hidden, and actuarial deficit in Armenia in 1995-2001. They are estimated using the definitions provided above in Chapter 1.

11. Horvath, Thacker, and $\mathrm{Ha}$ (1998) examine the early (1994-96) stabilization efforts by the Armenian Government. World Bank (2002) describes trends in Armenia's fiscal performance in 1997-2001. 


\section{Figure I. Real Exchange Rate Developments in Selected Cis Countries (relative to the US\$), 1994 $=100$}

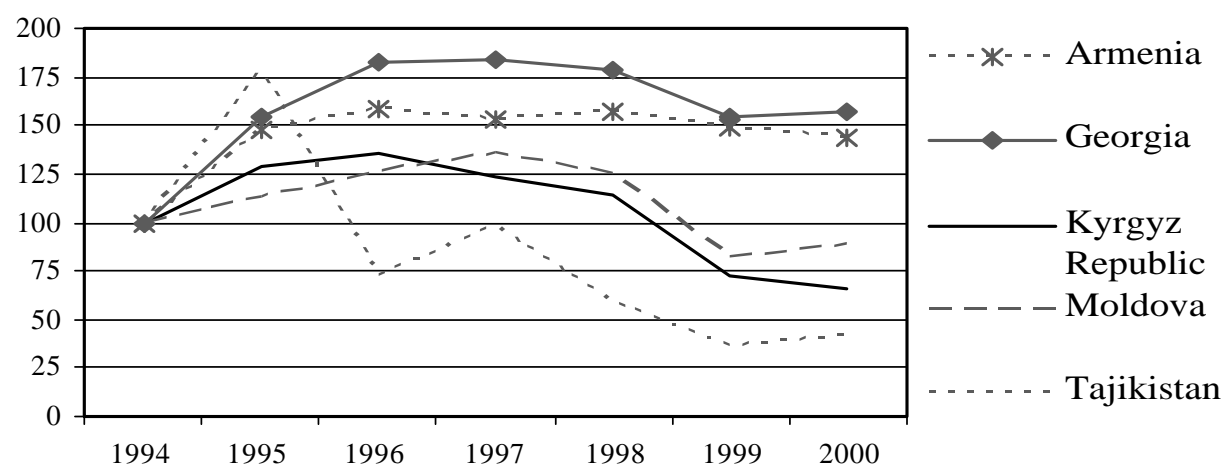

Source: IMF.

\section{Table 2. Net Present Value of External Debt, in Percent, 2000 and 2002}

\begin{tabular}{lccccc} 
& \multicolumn{2}{c}{$\begin{array}{c}\text { Ratio to Exports of Goods } \\
\text { \& Services (*) }\end{array}$} & & \multicolumn{2}{c}{$\begin{array}{c}\text { Ratio to Central } \\
\text { Government Revenue }\end{array}$} \\
\cline { 2 - 5 } & $\mathbf{2 0 0 0}$ & $\mathbf{2 0 0 2}$ & $\mathbf{2 0 0 0}$ & $\mathbf{2 0 0 2}$ \\
\hline Armenia, 2000 & 135 & 102 & 177 & n.a. \\
\hline Georgia & 128 & n.a. & 356 & 373 \\
\hline Kyrgyz Republic & 198 & 187 & 576 & n.a. \\
\hline Moldova & 139 & n.a. & 380 & 408 \\
\hline Tajikistan & 140 & 126 & 579 & \\
\hline
\end{tabular}

Source: World Bank (200 Ia), IMF.

Note: $(*)$ - Three-year moving average for exports.

\section{Figure 2. Average GDP Growth IN Selected CIS Countries, 1997-200I}

Average GDP growth, 1997-2001, annual, \%

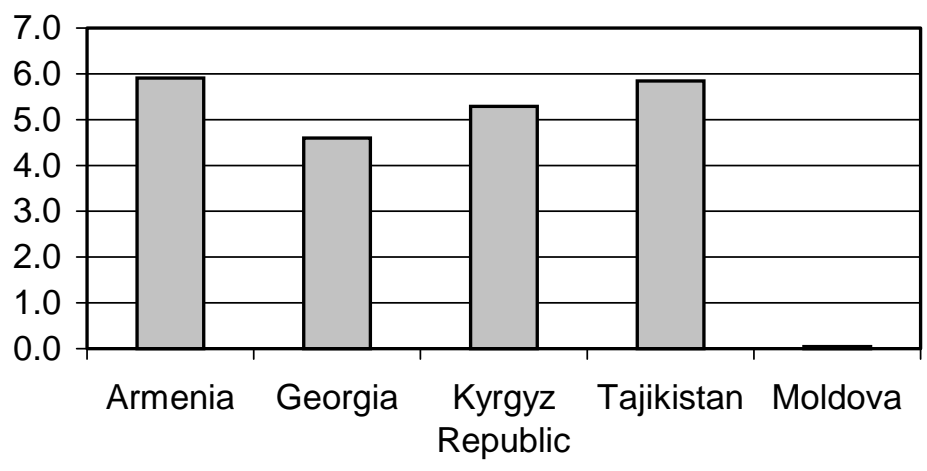




\section{Figure 3. Average AnNual Inflation In Selected CIS Countries, 1997-200I}

$$
\text { Average Inflation, consumer prices, \% }
$$

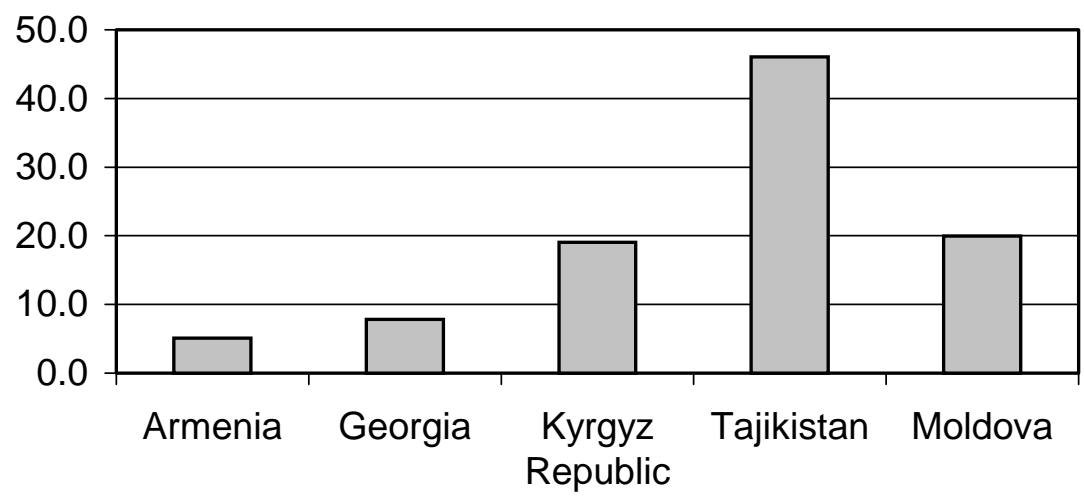

Source: World Bank.

Table 4 confirms some improvements in the fiscal performance of the Armenian Government starting in 1997. The average consolidated budget deficit (accrual) for 1997-2001 declined to an average of about 5.5 percent of GDP, from over 8 percent in the previous two years. This was a serious achievement, but clearly insufficient because it remained far above its sustainable medium-term level, which is estimated by the World Bank (2002) to be about 3.5 percent of GDP. ${ }^{12,13}$ However, it is worth noting that, as was shown in Table 3 , many of Armenia's neighbors managed to attain much larger improvements in their budget deficits in the mid-1990s, but this still did not give them sufficient fiscal strength to get through the Russia crisis of 1998 without being severely hit. Thus, conventional fiscal indicators do not help to explain significant differences in macroeconomic performance between Armenia and other low-income CIS economies.

The analysis of actuarial deficit in Table 4 is based on the consolidation of annual changes in five components of public liabilities (external and domestic debts, budget arrears, money supply, and payables (including arrears) of public energy companies) and two types of public assets (value of state holdings in the real sector and foreign exchange reserves of the Central Bank). The dynamics of debts accumulated by Armenia's energy sector represent most of the public sector's net liabilities accumulated outside of the Government budget. ${ }^{14}$ Annual changes in the value of public holdings were measured by amounts of privatization proceeds spent by the Government in the same year. ${ }^{15}$

Compared to the conventional deficit indicators, the changes in actuarial deficit point much more clearly to a major adjustment undertaken by the Government in 1997, when the hidden

12. It is believed that Armenia could afford a relatively high deficit levels for the next several years because its good access to highly concessional financing, including IDA, bilateral donors, and Diaspora's sources, in a combination with high growth rates keeps its debt profile sustainable.

13. The fiscal outcome for 2001 looks encouraging but it remains to be seen how sustainable it is.

14. This is primarily because main outstanding debts of non-energy SOEs in Armenia are those to their energy suppliers and to the government, i.e., they are the debts that are within the public sector and should be excluded in this exercise to avoid double counting.

15. The total for used privatization proceeds includes gas-for-equity swap in the energy sector, which has not been reflected in the budget. 


\begin{tabular}{|c|c|c|c|c|c|c|c|c|}
\hline \multirow{2}{*}{ TABLE 3.} & \multicolumn{8}{|c|}{$\begin{array}{l}\text { GENERAL GOVE } \\
\text { as Percent of GDP }\end{array}$} \\
\hline & 1996 & 1997 & 1998 & 1999 & 2000 & 2001 & $1996-98$ & $|999-0|$ \\
\hline \multicolumn{9}{|c|}{ Low Deficit Countries } \\
\hline Turkmenistan & 0.3 & 0 & -2.7 & 0 & -0.4 & 0.9 & -0.8 & 0.2 \\
\hline Belarus & 0 & -0.3 & -0.3 & -2.1 & -0.1 & -1.9 & -0.2 & -1.4 \\
\hline Azerbaijan & -2.8 & -1.6 & -3.9 & -4.7 & -0.6 & 0.9 & -2.8 & -1.5 \\
\hline Estonia & -1.5 & 2.2 & -0.3 & -4.6 & -0.7 & 0.4 & 0.1 & -1.6 \\
\hline Latvia & -1.4 & 1.4 & -0.8 & -3.9 & -3.3 & -1.9 & -0.3 & -3.0 \\
\hline \multicolumn{9}{|c|}{ Middle Deficit Countries } \\
\hline Tajikistan & -5.8 & -3.3 & -3.8 & -3.1 & -0.6 & -0.1 & -4.3 & -1.3 \\
\hline Ukraine & -3.2 & -5.6 & -2.8 & -2.4 & -1.3 & -1.6 & -3.9 & -1.8 \\
\hline Uzbekistan & -7.3 & -2.4 & -3.3 & -2.6 & -2.2 & -2.2 & -4.3 & -2.3 \\
\hline Lithuania & -4.5 & -1.8 & -5.9 & -8.5 & -2.8 & -1.9 & -4.1 & -4.4 \\
\hline \multicolumn{9}{|c|}{ High Deficit Countries } \\
\hline Russia & -8.9 & -8 & -7.9 & -3.1 & 3.1 & 2.6 & -8.3 & 0.9 \\
\hline Kazakhstan & -5.4 & -7.1 & -7.6 & -5 & -0.8 & 3.2 & -6.7 & -0.9 \\
\hline Moldova & -7 & -9.3 & -5.7 & -3.4 & -2.6 & -0.5 & -7.3 & -2.2 \\
\hline Georgia & -7.1 & -6.1 & -4.9 & -5 & -2.6 & -1.6 & -6.0 & -3.1 \\
\hline Armenia & -8.3 & -4.7 & -3.7 & -5.2 & -4.8 & -4.2 & -6.5 & -4.7 \\
\hline Kyrgyz Republic & -9.5 & -9.2 & -9.5 & -11.9 & -9.2 & -5.0 & -9.4 & -8.7 \\
\hline
\end{tabular}

Source: IMF, for Armenia - the most recent Government data.

deficit almost disappeared. ${ }^{16}$ While the following year was less successful, the average level of actuarial deficit in 1999-2001 was less than 7.0 percent of GDP, compared to more than 15 percent in 1995-96. Even more importantly, hidden deficits declined drastically after 1999 and stayed pretty small in 1999-01 (Figure 4). Figure 5 describes the structure of actuarial deficit, showing that in 1995-97 it was dominated by external borrowing, while later the actuarial deficit had a more diversified structure.

The overall level of deficit in the public sector in 1995-96 (of the order of 15 percent of GDP) was comparable to the one in Russia in the years before the 1998 crisis. Still, Armenia managed to avoid a default on government debts. The explanation to this fact relates to fundamental differences in sources of deficit financing in two countries. Fortunately for Armenia, its public sector deficit was not financed through short-term commercial borrowing. Instead, most financing came from long-term donor credits at subsidized rates. Another portion of funding came from the Russian energy suppliers, which later were paid in equity through debt-for-equity swaps. At the same time, the example of Georgia, which followed a riskier borrowing strategy than Armenia to finance its quasi-fiscal deficits and eventually had to go through debt restructuring by the Paris Club, gives another example of potential risks of not addressing quasi-fiscal problems in time.

Major reforms in the power sector, undertaken in 1997, made a critical contribution to improvements in the public sector balance in that year. The average electricity tariff was increased from $1.4 \mathrm{c}$ to $4.2 \mathrm{c}$, collections (especially in cash) improved, while barter payments were mostly phased out. An additional contribution to the sector's financial recovery was made through the

16. The factors that contributed to the improved macro and fiscal outcome in 1997 included: improved revenue performance, strengthened performance of the power sector, and shutting down the Nairit company for about six months. 


\begin{tabular}{|c|c|c|c|c|c|c|c|}
\hline & 1995 & 1996 & 1997 & 1998 & 1999 & 2000 & 2001 \\
\hline Ext Debt & 182.0 & 165.0 & 106.0 & 95.0 & 73.0 & 19.0 & 37.0 \\
\hline as \% of GDP & $14.16 \%$ & $10.33 \%$ & $6.53 \%$ & $5.00 \%$ & $3.96 \%$ & $0.99 \%$ & $1.74 \%$ \\
\hline Domestic Debt & 0.5 & 24.2 & 22.5 & -7.1 & 3.2 & 11.9 & 2.5 \\
\hline as \% of GDP & $0.04 \%$ & $1.51 \%$ & $1.39 \%$ & $-0.38 \%$ & $0.17 \%$ & $0.62 \%$ & $0.12 \%$ \\
\hline Energy Sector Arrears & 20.8 & 63.8 & $(18.3)$ & 47.4 & $(29.5)$ & $(10.6)$ & 14.7 \\
\hline as \% of GDP & $1.62 \%$ & $4.00 \%$ & $-1.13 \%$ & $2.49 \%$ & $-1.60 \%$ & $-0.55 \%$ & $0.69 \%$ \\
\hline Reserve Money & 36 & 22 & 7 & 1 & $(0)$ & 28 & 12 \\
\hline as \% of GDP & $2.83 \%$ & $1.36 \%$ & $0.45 \%$ & $0.05 \%$ & $-0.02 \%$ & $1.48 \%$ & $0.56 \%$ \\
\hline Budget Arrears & 0.0 & 0.0 & 2.8 & 10.2 & 38.0 & 38.5 & -2.9 \\
\hline as \% of GDP & $0.00 \%$ & $0.00 \%$ & $0.17 \%$ & $0.54 \%$ & $2.06 \%$ & $2.01 \%$ & $-0.14 \%$ \\
\hline Total stock of liabilities & 239.7 & 274.8 & 120.4 & I46.5 & 84.5 & 87.1 & 63.3 \\
\hline as \% of GDP & $18.64 \%$ & $17.20 \%$ & $7.42 \%$ & $7.7 / \%$ & $4.58 \%$ & $4.54 \%$ & $2.97 \%$ \\
\hline Privatization proceeds & 0.0 & 0.0 & 0.1 & 82.9 & 53.0 & 66.3 & 36.3 \\
\hline as \% of GDP & $0.00 \%$ & $0.00 \%$ & $0.01 \%$ & $4.36 \%$ & $2.87 \%$ & $3.46 \%$ & $1.70 \%$ \\
\hline Gross Reserves of CBA & $(29.5)$ & $(58.9)$ & $(74.3)$ & $(98.0)$ & 9.9 & 0.6 & $(3.4)$ \\
\hline as \% of GDP & $-2.29 \%$ & $-3.68 \%$ & $-4.58 \%$ & $-5.16 \%$ & $0.54 \%$ & $0.03 \%$ & $-0.16 \%$ \\
\hline Total Loss of Assets & (29.50) & $(58.85)$ & (74.15) & $(15.10)$ & 62.87 & 66.93 & 32.90 \\
\hline$\%$ of GDP & $-2.29 \%$ & $-3.68 \%$ & $-4.57 \%$ & $-0.79 \%$ & $3.41 \%$ & $3.49 \%$ & $1.55 \%$ \\
\hline PSB (Actuarial Deficit) & 210.19 & 215.93 & 46.20 & 131.38 & 147.33 & 154.03 & 96.17 \\
\hline \multirow{2}{*}{$\begin{array}{l}\text { Actuarial Deficit (as \% of GDP) } \\
\text { as percent of GDP }\end{array}$} & $16.35 \%$ & $13.52 \%$ & $2.85 \%$ & $6.92 \%$ & $7.99 \%$ & $8.03 \%$ & $4.52 \%$ \\
\hline & \\
\hline Budget Deficit (accrual) & $8.9 \%$ & $8.3 \%$ & $4.9 \%$ & $4.2 \%$ & $7.3 \%$ & $6.7 \%$ & $3.8 \%$ \\
\hline \multirow{2}{*}{$\begin{array}{l}\text { Hidden Deficit } \\
\text { Memorandum Items }\end{array}$} & $7.45 \%$ & $5.22 \%$ & $-2.05 \%$ & $2.72 \%$ & $0.69 \%$ & $1.33 \%$ & $0.72 \%$ \\
\hline & \\
\hline Conventional Budget Deficit (cash) & $8.9 \%$ & $8.3 \%$ & $4.7 \%$ & $3.7 \%$ & $5.2 \%$ & $4.8 \%$ & $4.2 \%$ \\
\hline GDP $(\$$ million $)$ & 1,286 & 1,597 & 1,623 & 1,899 & $\mathrm{I}, 845$ & 1,917 & 2,129 \\
\hline Exchange rate, eop & 402 & 435 & 495 & 522 & 524 & 552 & 562 \\
\hline
\end{tabular}

Note. A. For the energy sector: debt estimates include regular commercial debts (e.g. to banks) and arrears on inputs, wages and other private sector creditors, but exclude debts to the Government. Also include debt write-offs. B. For the Government: debt estimates exclude publicly guaranteed debts.

Source: Authors' estimates based on the data from the Armenian MOFE, Pension Fund, Ministry of Energy, Central Bank, and the IMF.

operation of the nuclear power plant, which was re-started in late 1995 (World Bank 1999b, pp.75-84).

The comparison between actuarial and conventional (accrual) deficit estimates (Figure 6) show that the actuarial deficit has been declining much faster than the traditional budget deficit, especially since 1999. A larger part of the adjustment took place outside of the conventional fiscal system. This confirms that the real fiscal adjustment in Armenia was more significant than one may assess based on changes in traditional budget deficit data.

At the same time, these two deficit indicators in Armenia have been comfortably close for the entire period (except for 1998). This means that the combined deficit of public sector operations unaccounted in the budget (including money supply) was not much larger than the ongoing asset accumulation by the public sector-that is, accumulation of foreign reserves by the CBA.

The conventional fiscal analysis underestimates this improvement in part because it ignores the quite impressive build-up of foreign exchange reserves by the Armenian authorities (Figure 7), 


\section{Figure 4. Armenia: Hidden Deficit as Percent of GDP, |995-200I}

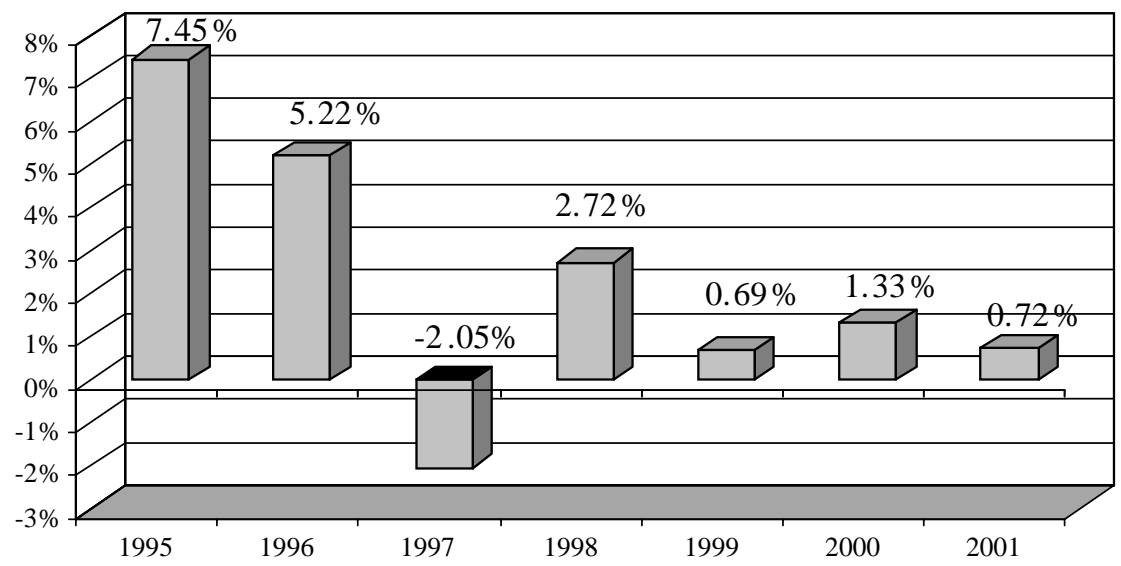

\section{Figure 5. Armenia: Composition of Actuarial Deficit} as Percent of GDP

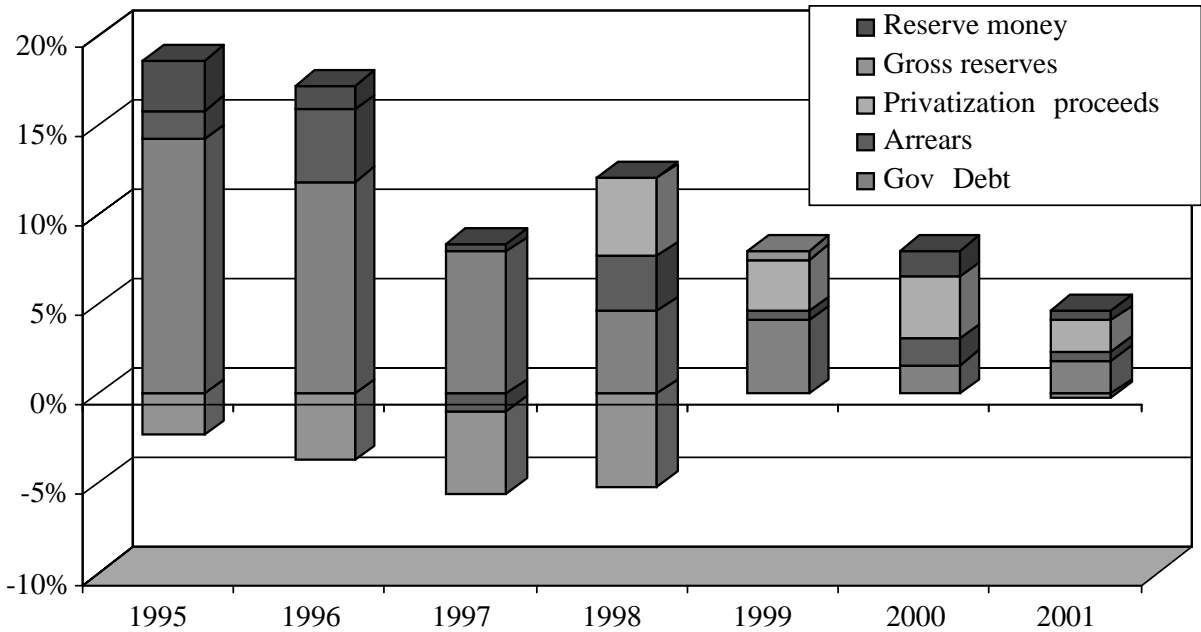

which increased from \$109.5 million (8.5 percent of GDP) in 1995 to $\$ 340.6$ million in late 1998 (17.9 percent of GDP). Taking into account foreign exchange reserves accumulation ${ }^{17}$ is actually rather important for adequate assessment of changes in the net worth of the Government as well as for basic Government fiscal performance during the period.

The decline in the hidden deficit confirms that at least in a macroeconomic sense budget adjustment in Armenia in the 1990s was quite genuine. It was not accompanied by excessive growth of hidden off-budget liabilities. In other words, unaccounted leakage from the system was quite modest.

17. In Armenia borrowing from the IMF to build CBA reserves was one of the significant factors that contributed to high growth rates of the total external debt. 


\section{FIgURE 6. ARMENIA: ACCRUAL AND ACtUARIAL DeFICITS Percent of GDP}

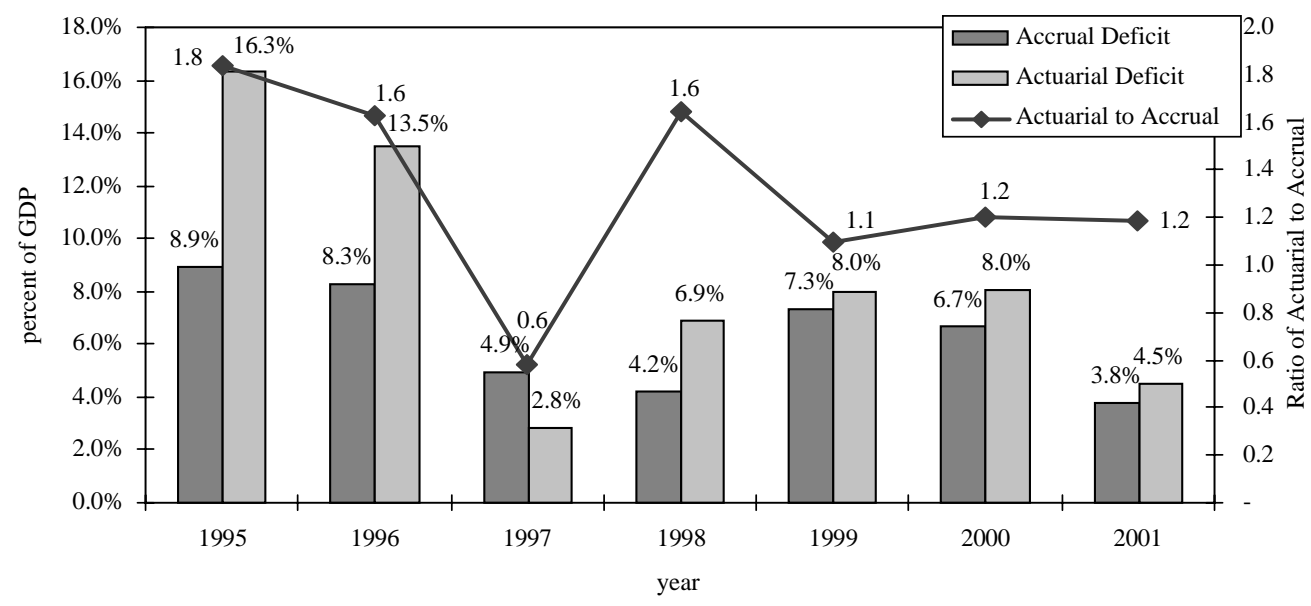

Figure 7. Gross INTERNATIONAL RESERVES as Percent of GDP, Year End

\section{Gross Reserves, as percent of GDP}

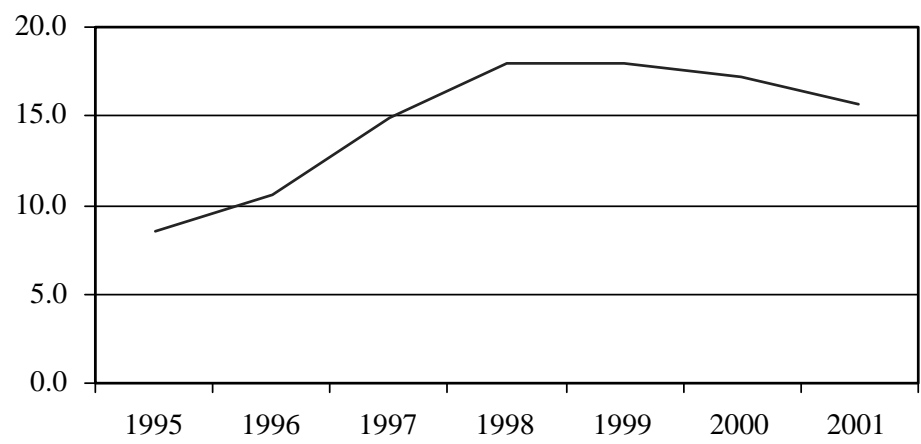

Source: CBA.

Such a trend in fiscal adjustment in Armenia could be compared with broader regional patterns. Figure 8 presents the case of Moldova, which is selected as a rather typical CIS economy that showed an unsustainable fiscal performance in most of the 1990s. As the diagram suggests, for each year between 1995 and 1998, the estimated actuarial deficit of the public sector for Moldova exceeded its accrual Government deficit by 1.5 to 2 times. The average reported budget deficit for this period was 9 percent of GDP, while the actuarial deficit was over 16 percent. This means that a significant part of the public deficit remained off-budget, with public liabilities accumulated at the balance sheets of energy and utility companies, while the growth in overall public debt exceeded the budget deficit's financing requirements. Such a financial performance was clearly unsustainable. This led to a major macroeconomic crisis in 1998 (triggered by the Russia crisis) and was followed 


\section{Figure 8. Moldova: FiscAL AdJuStMent, 1995-2000} Percent of GDP

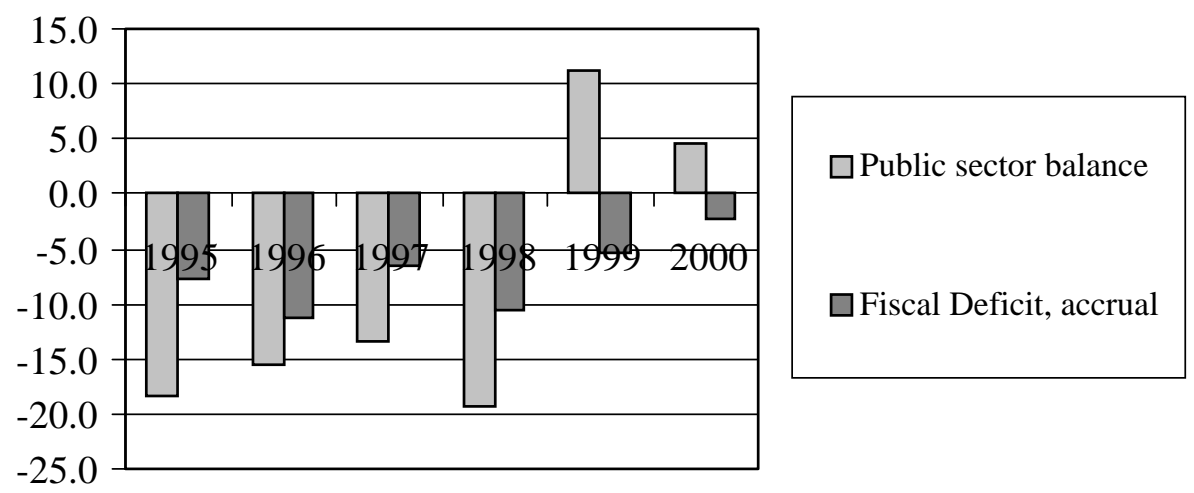

by a radical fiscal adjustment in 1999-2000, supported by external debt relief, debt-for-equity swap with Russia, and erosion of domestic debts due to inflation and devaluation.

Overall, there is sufficient evidence to conclude that the fiscal adjustment in Armenia in 1997-01 was driven by the reduction in quasi-fiscal (hidden) deficits and phasing out of quasifiscal subsidies. Hidden deficits in Armenia were smaller in 1997-98 than in other low-income CIS countries, and the Government of Armenia has further advanced the consolidation of its fiscal system in 1999-2001 through reduction in the overall public sector deficit, including both budgeted and quasi-fiscal portions. However, these positive processes still have to be further advanced to ensure longer-term fiscal sustainability. 
Chapter 4

HidDEN BUdget SUBSIDIES,
QUASI-FISCAL SUbSIDIES
AND CONTINGENT
LIABILITIES IN ARMENIA

\section{Definitions}

In this chapter we try to distinguish between three inter-related phenomena:

(a) Hidden budget subsidies represent an ultimate cash transfer from the Government to the enterprise and household sectors that is either not identified as a subsidy in the Government's accounts or not reflected in these accounts at all. The hidden subsidies include, for example, direct budget credits, tax exemptions and tax arrears, enterprise transfers from state extra-budgetary funds, enterprises' gains from import and export quotas, and recapitalization of troubled SOEs. In some particular cases, hidden subsidies are reflected (but more frequently they are not), in the official budgetary documents (while they are not called "subsidies"), and often they are used to clear debts (that is, finance them) that emerge as a result of either: quasi-fiscal subsidies provided earlier or accumulation of contingent liabilities (CLs).

(b) Quasi-fiscal activities/subsidies represent provision of implicit subsidies by public sector entities that operate outside of the regular Government budget such as a Central Bank, state-owned commercial banks, state enterprises in energy and public utilities, etc. In the case of public utilities and other "important" state-owned enterprises, they usually finance such subsidies through a heavy debt accumulation. There is an implicit assumption by creditors and suppliers that the Government will step up and bail out these companies if necessary to prevent their insolvency.

(c) Contingent liabilities represent liabilities that potentially may (or may not) become explicit claims on the government budget in the future periods. The real value of CLs is usually known only ex post, while the real time estimates for CL levels are often derived from stochastic models. Traditional examples of CLs include government guarantees on commercial credits, 
operations of public social and medical insurance funds, risks/costs associated with the collapse of banking systems, ${ }^{18}$ as well as costs of possible currency crises.

\section{Incidence of QFAs and CLs in Armenia}

As mentioned above, compared to other low-income and energy-dependent CIS economies, Armenia has shown somewhat stronger macroeconomic and fiscal discipline, which is, among other things, associated with utilization of fewer quasi-fiscal instruments. In this regard, the following features of Armenia's fiscal system should be mentioned:

Armenia introduced quite a liberal trade regime (rated 1 by the IMF) very early in transition; it automatically eliminated many possibilities for quasi-fiscal subsidization, such as through import quotas and multiple exchange rates.

The Armenian tax legislation does not leave room for individual tax exemptions ${ }^{19}$ to be granted by special Government decisions to specific, usually the largest, enterprises.

Since 1996, the Central Bank of Armenia has become quite conservative in its monetary policy and increasingly independent from Government pressures, which greatly reduced possibilities for using direct CBA credits and other interventions as a quasi-fiscal instrument.

The Government has created a rather restrictive environment that in practice has prevented Armenian local governments and the Pension Fund from borrowing on commercial terms.

Armenian extra-budgetary funds, while still significant, ${ }^{20}$ have been spent almost entirely on additional financing of government administration, but not financing of investment programs or rehabilitation of the enterprise sector.

The Government has mostly escaped the trap of non-cash substitutes; offset operations between budget (arrears) and largest taxpayers (tax debts) were rather limited. It is estimated that in 1997-98 only 10 percent of sales of the largest enterprises were paid in barter (World Bank 2001c).

The Armenian social insurance system (the Pension Fund) has been considered quite fiscally sustainable, mostly due to the very low level of old age pensions paid to most retirees (PADCO 2001).

The banking system was fully privatized and at the same time remained quite small, with limited possible spillover from a potential banking crisis to the rest of the economy.

The possibility of a currency crisis remained low due to an aggressive policy of accumulation of foreign reserves (see Figure 7 above), which have been rather high since 1998 in relation to both imports and dram M2.

This does not mean that QFAs in Armenia were of no importance. However, both channels and sources of quasi-fiscal financing were heavily concentrated, which makes it somewhat easier to quantify both their intensity as well as the allocation of associated benefits among their recipients.

\section{Hidden Subsidies}

Soft low-interest budget credits have been the main channel of hidden Government support to struggling SOEs in Armenia. In most cases, these credits were not repaid but written-off by the Government. Most of these credits went to state energy and utility companies as a de facto compensation (financing) for continuous quasi-fiscal subsidization of the rest of the economy by

18. As in other developing economies, public costs of banking crises in transition are quite high. For instance, costs of bank restructuring in Latvia were estimated as 22 percent of GDP and in Slovakia as 12 percent of GDP (Alam and Sundberg 2002).

19. In Kyrgyzstan, for instance, various tax exemptions amounted to 5-7 percent of GDP a year (Asad and Sundberg 2002).

20. In 2000 the total volume of EBFs administered by individual ministries and government agencies in Armenia amounted to 0.7 percent of GDP (World Bank 2002). 
these companies. For any practical purpose, these credits represent traditional budget subsidies and should be reclassified in the Government's books as such. In 1997-2001, the annual flow of budget credits amounted on average to about 0.7 percent of GDP (Table 5 ).

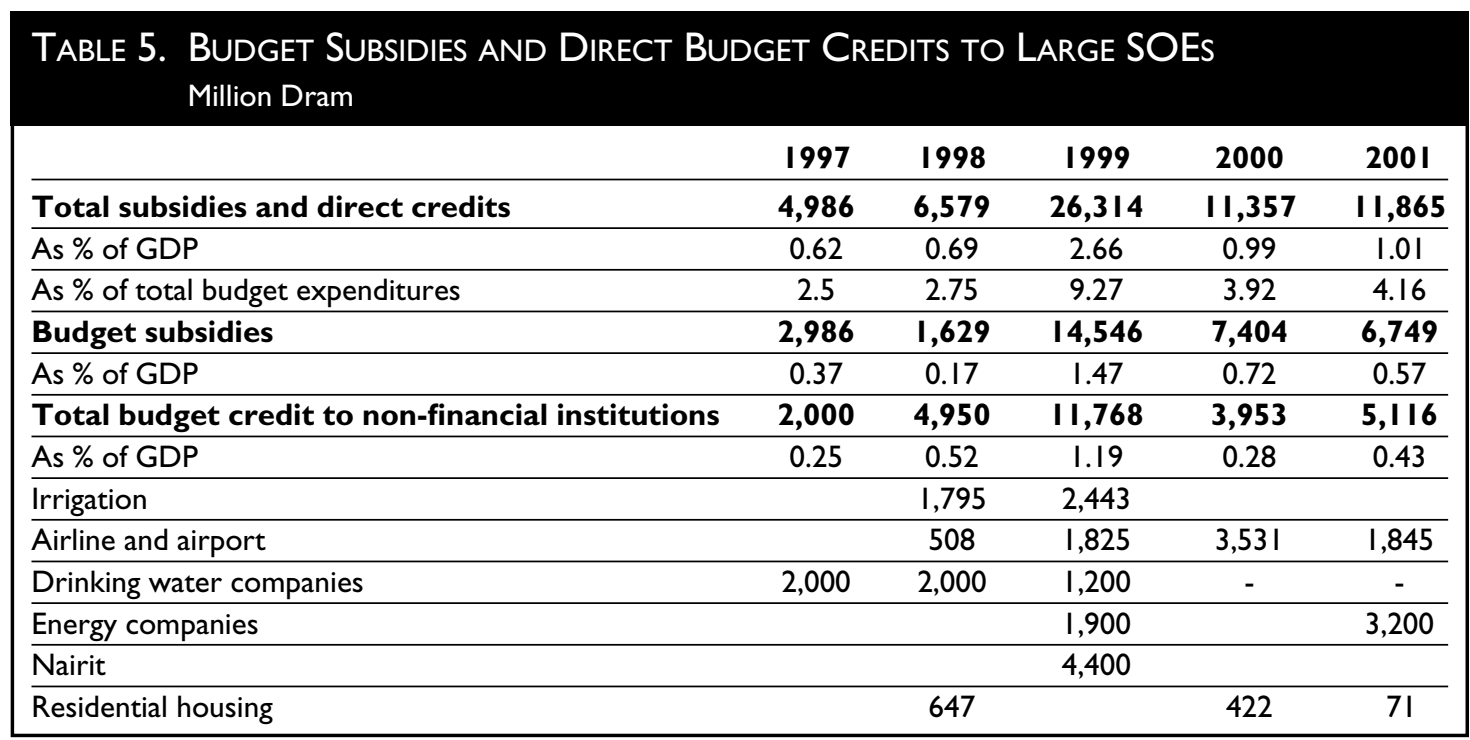

Source: World Bank (2002).

Tax arrears represent another significant channel of hidden subsidization. While the level of tax arrears in Armenia was somewhat lower than in most CIS economies, it still constitutes a major fiscal burden. The average annual increase of tax arrears in 1997-2001 was close to 1 percent of GDP (Table 6), despite a few write-offs of such debts. ${ }^{21}$

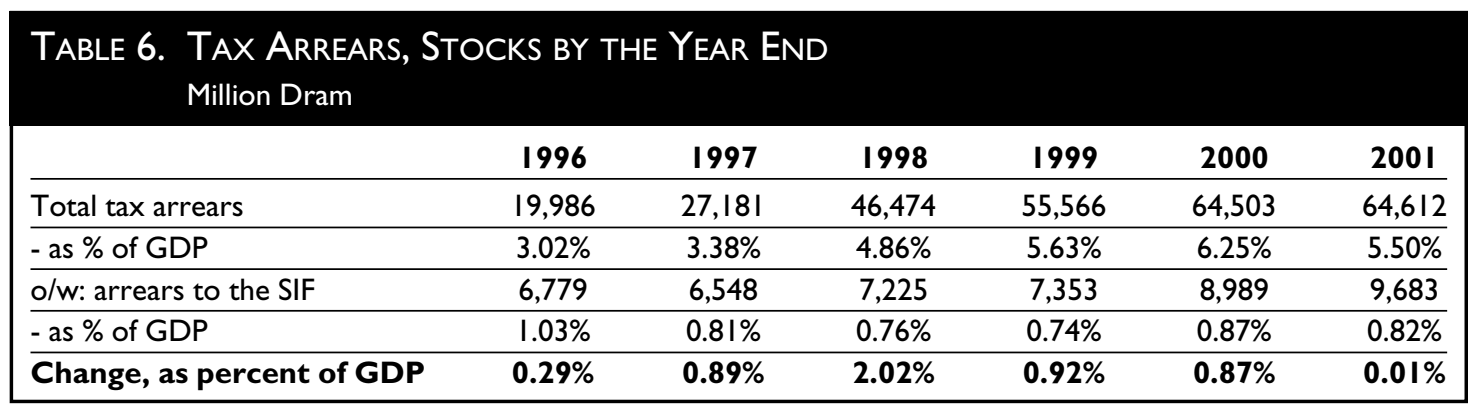

Note: Excluding fines and penalties.

In Armenia, tax arrears are heavily concentrated. In late 2001, the 30 largest debtors held 47 percent of the total tax debt and 56 percent of the total debt to the Pension Fund (SIF). Tax liabilities of the energy sector amounted to about a third of the total tax debts.

Use of privatization proceeds. In general, the Armenian Government utilized the privatization proceeds through the regular budgetary process, while disbursements from the Special Privatization

21. For instance, in 1997 the Government wrote-off 42 billion Dram (2.2 percent of GDP) in tax arrears of the power sector. 
Account were made mostly for public investment purposes as approved by the annual budget law. However, privatization of the Armenian gas distribution network in 1998 was structured in such a way (gas-for-equity swap) that its financial results remained outside of the country's fiscal system. In fact, the gas-for-equity swap was the largest hidden subsidy in recent Armenian history. The gas, received by Armenia as a payment in the course of four years, was transferred to the power sector as a de facto free resource to support electricity generation by the thermo power plants.

If the swap were settled at market prices, then the total value of this subsidy would be about US\$134.92 million, equivalent to an average annual subsidy of 1.8 percent of GDP for 1998-2001 (Table 7).

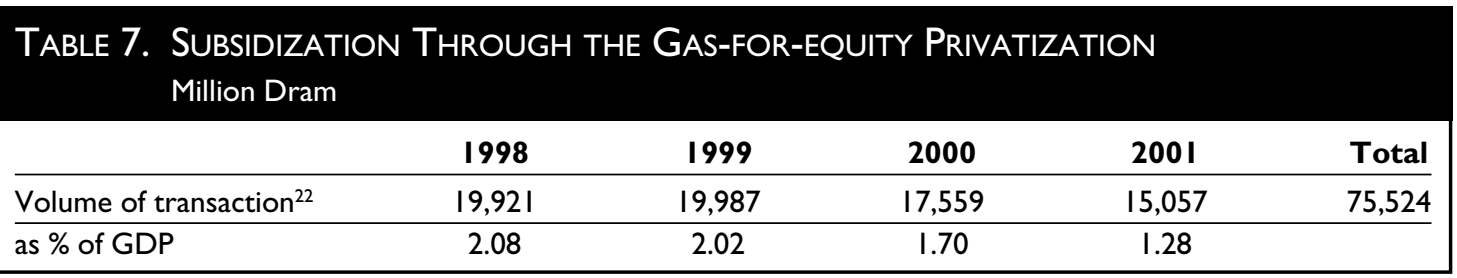

Source: Ministry of Energy.

Government external borrowing to support operations of companies in the E⿺ $U$ sector. Accumulation of debts related to import of energy inputs made a significant contribution to the build-up of Armenia's overall external debt in the 90s. About a half of the non-concessional bilateral debts (amounting to about $\$ 80$ million or 4 percent of GDP) originated in the energy sector. The Government accumulated external debts on behalf of the energy and utility sector through two primary channels:

(a) New credits received to finance import of energy inputs, other recurrent costs and capital rehabilitation; and

(b) Government repayments of the debts initially accumulated by the energy sector to external suppliers. ${ }^{23}$

Table 8 summarizes the amount of resources received by the E\&U sector from the Government through such debt transfers, i.e., the Government's accumulation of external debts of behalf of the sector. These estimates reflect both new disbursements (an inflow of credit funds in 1997-2001) and the costs of Government's service of earlier borrowing (1992-96) that benefited the E\&U sector. Note that this Government support to the sector has never been reflected in the budget as subsidies, but usually treated as either public investments or other expenditures. This is why we consider these operations as hidden Government subsidies. Annex A provides a full list of such credits.

Table 9 summarizes our estimates for hidden budget subsidies to the enterprise (mostly E\&U) sector. It suggests that in 1998-1999 the annual volume of hidden public support exceeded 6 percent of GDP. Table 10 presents our final estimates for the overall subsidy flow in the Armenian economy, reflecting explicit, hidden, and quasi-fiscal subsidies. In 1998-1999, total average annual subsidies exceeded 10 percent of GDP, with hidden subsidies accounting for more than 60 percent of the total. At the same time, one should note some reduction in QF subsidies in 1999, which was a reflection of Government's efforts to increase cost recovery in tariffs, improve payment discipline, and reflect energy subsidies somewhat more adequately in the budget. Overall, our estimates in Tables 9 and 10 reflect excessive subsidization of final consumers in the energy and utility sector in

22. The value of the gas-equity swap was estimated based at $\$ 63.6$ for every $1000 \mathrm{M} 3$ of received gas, which is the sum of $\$ 53 / 1000 \mathrm{M} 3$ price of gas and 20 percent VAT.

23. Initially, fuel for energy generation (natural gas and nuclear fuel) was imported to Armenia under commercial contracts, signed by energy companies. With time, the government took on the responsibility for these debts. 


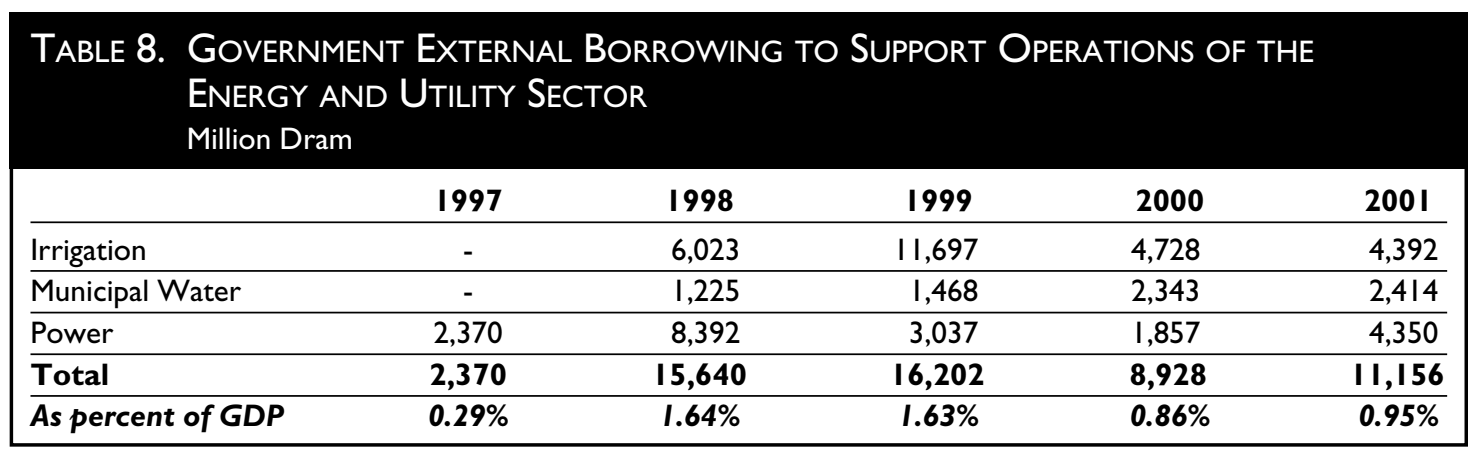

Source: Ministry of Finance and Economy.

$\begin{aligned} & \text { TABLE 9. TOTAL HIDDEN SubsidIES } \\
& \text { as Percent of GDP }\end{aligned}$
\begin{tabular}{lccccc|} 
& & & & \\
& $\mathbf{1 9 9 7}$ & $\mathbf{1 9 9 8}$ & $\mathbf{1 9 9 9}$ & $\mathbf{2 0 0 0}$ & $\mathbf{2 0 0 1}$ \\
\hline Budget credits & 0.25 & 0.52 & 1.19 & 0.38 & 0.43 \\
\hline Change in tax arrears & 4.36 & 2.08 & 1.53 & 0.45 & -0.32 \\
\hline Privatization proceeds & 0.00 & 2.08 & 2.02 & 1.70 & 1.28 \\
\hline Debt transfers & 0.29 & 1.64 & 1.63 & 0.86 & 0.95 \\
\hline Total & $\mathbf{4 . 9 1}$ & $\mathbf{6 . 3 2}$ & $\mathbf{6 . 3 7}$ & $\mathbf{3 . 4 0}$ & $\mathbf{2 . 3 4}$ \\
\hline
\end{tabular}

\begin{tabular}{|c|c|c|c|c|c|}
\hline & 1997 & 1998 & 1999 & 2000 & 2001 \\
\hline Budgeted subsidies (a) & 0.37 & 0.17 & 1.47 & 0.72 & 0.57 \\
\hline Hidden subsidies (b) & 4.91 & 6.32 & 6.37 & 3.40 & 2.34 \\
\hline QF subsidies $(c)$ & 4.17 & 4.50 & 2.91 & 2.25 & 1.54 \\
\hline Energy non-payments & 3.83 & 4.02 & 2.20 & 1.95 & 1.34 \\
\hline Water non-payments & 0.33 & 0.47 & 0.70 & 0.30 & 0.19 \\
\hline Total subsidies & 9.45 & 10.99 & 10.75 & 6.37 & 4.45 \\
\hline - o/w: reflected in the budgeted (a) & 0.62 & 0.69 & 2.66 & 0.99 & 1.01 \\
\hline - as $\%$ of total & 6.6 & 6.3 & 24.7 & 15.5 & 22.6 \\
\hline
\end{tabular}

Source: Authors' estimates.

Notes: (a) per Table 5; (b) per Table 9; (c) as explained in the next chapter.

the late 1990s, which generated a need for Government support to the energy sector through various types of explicit and implicit subsidies. Figure 9 illustrates the intensity of various channels of subsidization.

Both Tables 9 and 10 also show a considerable decline in both hidden and total subsidies in 2000 and 2001. Still, less than a quarter of total subsidies has been reflected in the budget in 2001.

\section{Quasi-fiscal Subsidies}

As in many other CIS countries, QFAs in Armenia were heavily concentrated in the energy and utility (E\&U) sector. This happened due to three main reasons, partially described earlier: (a) the sector was dominated by large state-owned companies with weak corporate governance structures 


\section{Figure 9. Budgeted Subsidies, Hidden SUBSIDIES, ANd QUASI-FISCAL SUBSIDIES} as Percent of GDP

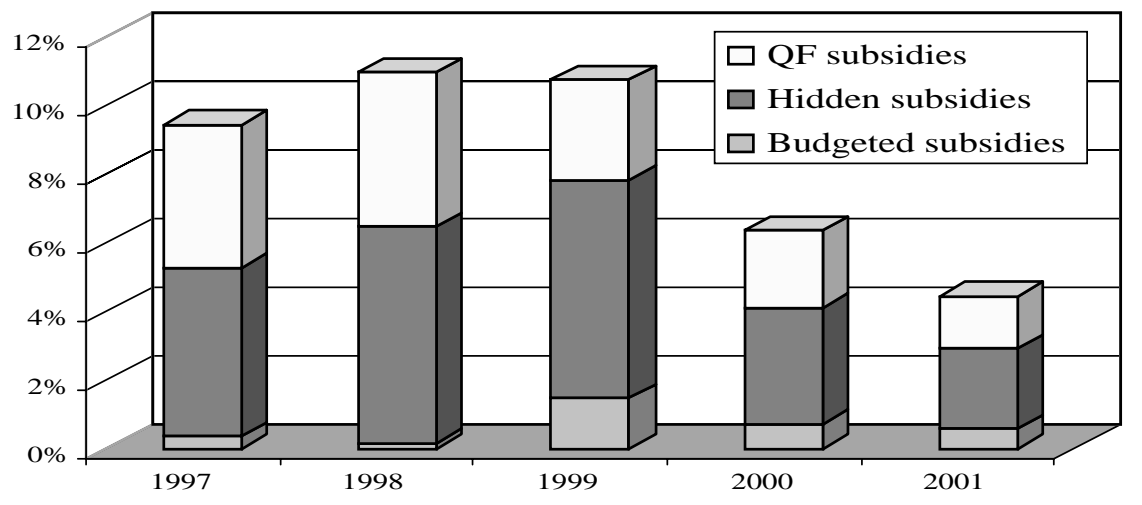

and heavy political influence; (b) the Government was not prepared for radical reforms in the E\&U sector because of the concerns regarding the possible social and political implications of such a reform; and (c) technical peculiarities of the inherited infrastructure networks led to additional obstacles to improvements in sectoral performance, in particular making it difficult to cut off nonpaying customers.

The Figure 10 describes the general organization of quasi-fiscal financing in Armenia. The central position in the diagram is occupied by the flow of quasi-fiscal subsidies from the energy

\section{Figure 10. Fiscal AND QUASI-FISCAL FINANCING OF QUASI-FISCAL SUBSIDIES IN THE ENERGy SECTOR}

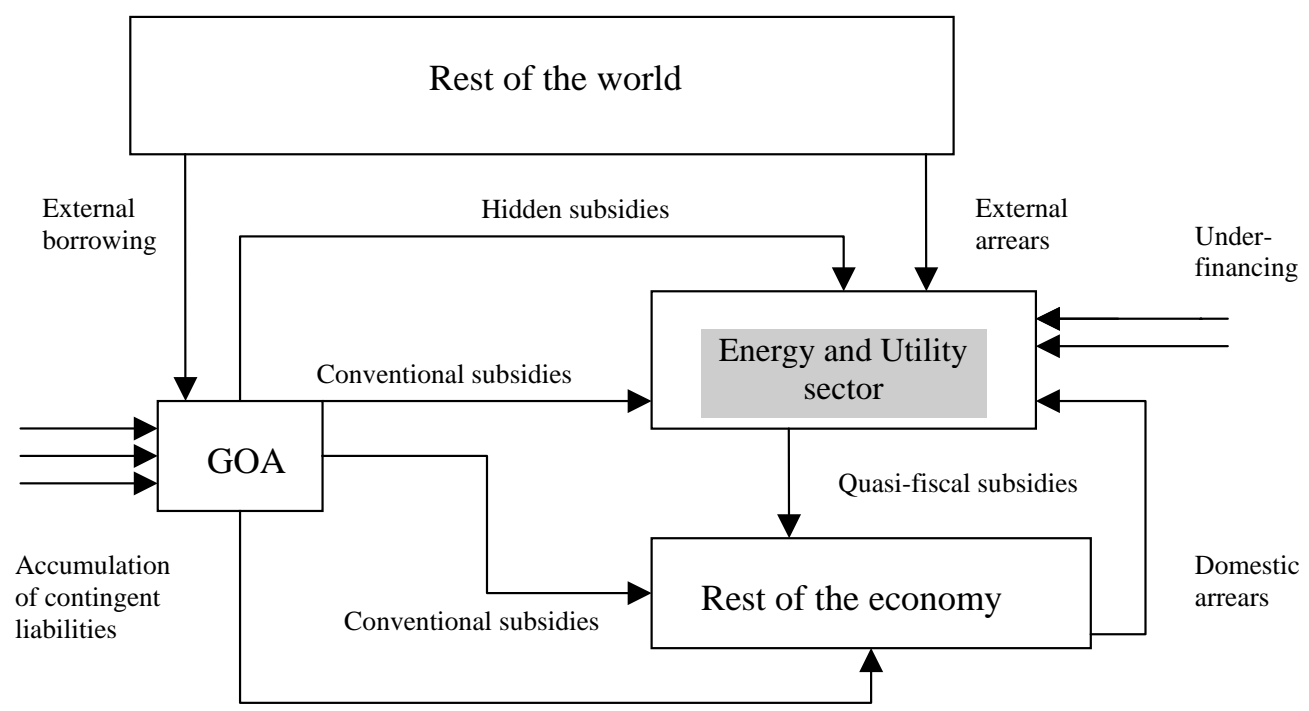

Hidden subsidies 
and utility sector to the rest of the economy. Historically, as soon as the accumulation of these subsidies became unaffordable for the sector and could result in the interruptions of energy supply to the country, the Government has been forced to intervene by providing additional financial support to both subsidy providers in the E\&U sector and subsidy recipients in the water, irrigation, and transportation sectors, as well as to the largest SOEs in manufacturing. Such Government financial support was granted both as conventional and as hidden subsidies. Overall, however, the Government was not able to provide a sufficient financial compensation to the $E \& U$ sector from its own resources. A large part of the ultimate financing of quasi-fiscal subsidies was provided by external government borrowing, arrears (domestic and external) of companies in the E\&U sector, and by under-financing of critical maintenance and rehabilitation spending in the sector.

The E\&U sector has subsidized its customers through two main channels - low tariffs and non-payments. ${ }^{24}$

Subsidization through tariffs in Armenia has been rather modest (by regional standards). ${ }^{25}$ Since early 1999, most tariffs (in power, water, and heating) have been sufficient (if collected) to cover the respective companies' operational costs as well as a portion of capital costs. Most cross subsidies through tariffs (provided through discounted tariffs to privileged groups of the population) were eliminated in mid-1997. At the beginning of 1999, the Government introduced a new average electricity tariff of $4.5 \mathrm{c}$ per $\mathrm{kwh},{ }^{26}$ which at that time was among the highest in the CIS (Table 11). The available estimates suggest that the volume of tariff subsidies amounted to 2 percent of GDP in 1997 and 1.5 in 1998, but in 1999-2000, the remaining tariff subsidies (mostly in irrigation) did not exceed 0.5 of GDP a year (World Bank 2001c). Households received at least twothirds of this amount, while commercial enterprises benefited from the rest.

Subsidization through non-payments, therefore, has been the main channel for quasi-fiscal subsidization. ${ }^{27}$ The culture of non-payment is well rooted in Armenia and it supports long chains of overdue payables within the economy. The overall annual flow of non-payments in the main utilities amounted to 8.7 percent of GDP in 1996 and 7.0 in 1998, but has been reduced considerably since 1999 (when it was 3.4 percent of GDP) due

\begin{tabular}{|c|c|c|}
\hline \multicolumn{3}{|c|}{$\begin{array}{l}\text { TABLE I I. ELECTRICITY T } \\
\text { ECONOMIES IN } \\
\text { WITHOUT VA } \\
\text { US cent per kwt }\end{array}$} \\
\hline & Residential & Industry \\
\hline Armenia & 3.6 & 3.0 \\
\hline Azerbaijan & 2.1 & 2.7 \\
\hline Bulgaria & 3.5 & 4.1 \\
\hline Georgia & 3.7 & 3.0 \\
\hline Estonia & 4.2 & 4.1 \\
\hline Kazakhstan & 2.2 & 2.1 \\
\hline Kyrgyz Republic & $0.004-1.9$ & $1.3-1.6$ \\
\hline Latvia & 5.3 & 4.4 \\
\hline Lithuania & $4.7-5.8$ & 4.3 \\
\hline Moldova & $3.6-4.7$ & 4.7 \\
\hline Russia & 1.5 & 1.3 \\
\hline Ukraine & 2.4 & 3.4 \\
\hline Uzbekistan & 0.4 & $0.4-0.6$ \\
\hline
\end{tabular}

Source: World Bank.

Note: Residential tariffs include low voltage consumers other than households in Armenia, Georgia, Estonia, Latvia, and Moldova.

24. Electricity consumers also received subsidies through one more, least transparent channel, which is so called excessive losses in the power distribution system (and is a conventional theft in most cases), which allowed specific groups of consumers to receive electricity without both payment and any registration.

25. For instance, in Kyrgyzstan the total quasi-fiscal deficit in the energy sector amounted to 9 percent of GDP in the mid-1990s, primarily due to low energy tariffs (World Bank, 2001b).

26. Including VAT of 20 percent.

27. Gaddy and Ickes (1998) provide a detailed discussion of subsidization through non-payments in Russia. 
to a stronger Government reform effort (Table 12). Chapter V provides a detailed analysis of subsidization through non-payments.

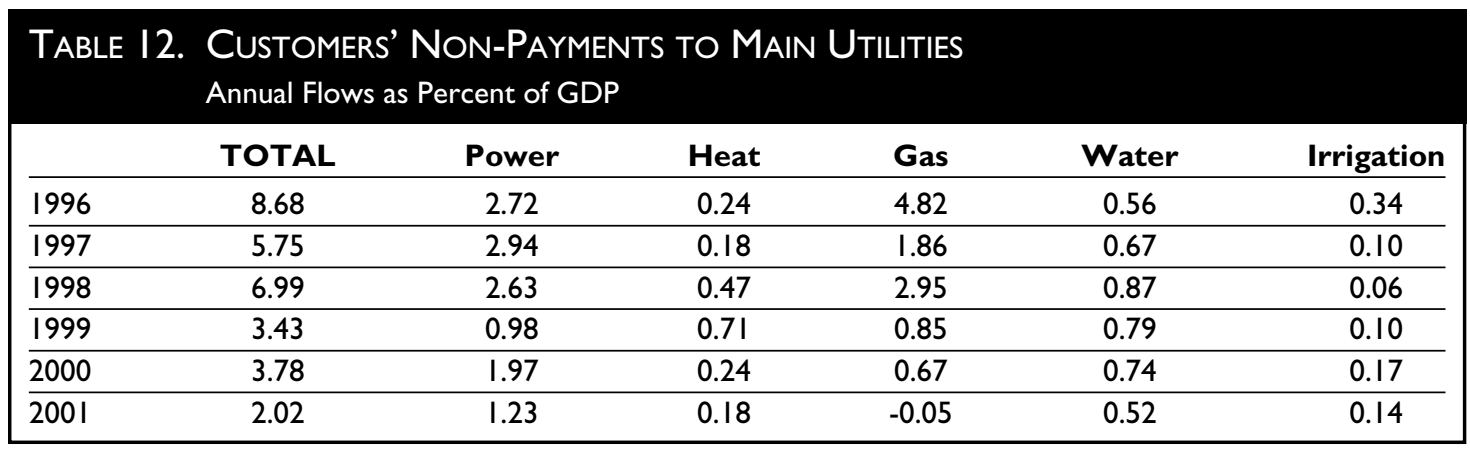

Source: Authors' estimates based on Annex B.

This excessive subsidization of the rest of the economy, complemented by poor financial management in the sector, naturally resulted in major losses, accumulated by public companies in utilities and infrastructure. These losses, to the extent that they are financed by borrowing and other debts to the private sector, represent the single largest component of quasi-fiscal deficits in Armenia. This is quite typical for economies in transition. What makes Armenia a little different is that: (a) such deficits were somewhat smaller; and (b) a relatively larger part of these deficits was admitted to be a direct liability of the state, and therefore was made rather explicit. As was shown above, to reduce the outstanding debts in the sector, the Government has gradually expanded the provision of E\&U companies with direct and hidden budget subsidies through various channels.

\section{Contingent Liabilities}

Government Guarantees on Commercial Borrowing. A relatively large part of the total banking credit in Armenia was granted to the enterprise sector under explicit and implicit guarantees. Explicit guarantees have been limited (Table 13), while implicit ones have been quite common. The energy companies have been the largest borrowers from the banking system. Their share has been approaching 40 percent of the total outstanding banking credit to the enterprise sector in 1998. This over-exposure to the energy sector derived from direct Government pressure on banks, complemented by the perception that the energy companies would always be bailed-out by the state. The share of banking credits to the energy sector gradually declined over 1998-2001 (Table 14) but still remained high, which represents a considerable risk for the banking sector as well as for the budget.

Under-financing of Maintenance and Rebabilitation. Under constant fiscal pressure since early in transition, the Government of Armenia has continuously underfinanced its basic

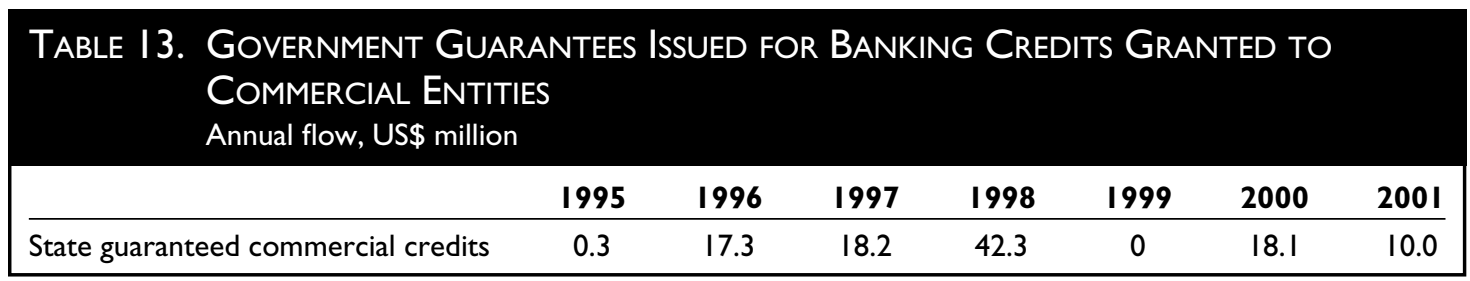

Source: MOFE. 


\begin{tabular}{|c|c|c|c|c|}
\hline & 1998 & 1999 & 2000 & 2001 \\
\hline Total credit to the economy & 81,608 & 90,127 & 109,319 & 102,669 \\
\hline Credit to the power sector & 31,121 & 23,814 & 22,605 & 23,941 \\
\hline — share in the total & $38.1 \%$ & $26.4 \%$ & $20.7 \%$ & $23.3 \%$ \\
\hline Credit to the water/irrigation sector & 102 & 89 & 1,419 & 67 \\
\hline — share in the total & $0.1 \%$ & $0.1 \%$ & $1.3 \%$ & $0.1 \%$ \\
\hline
\end{tabular}

Source: NSS, CBA, Ministry of Energy, State Water Committee.

infrastructure. Thus, de-capitalization of the main state energy and utility companies was another source of financing for quasi-fiscal subsidies provided by the E\&U sector. The total average annual amount of underfinancing in the late 1990 s is conservatively estimated as 2.2 percent of GDP (Table 15).

\begin{tabular}{|c|c|}
\hline Total & US\$45 million (or $2.2 \%$ of GDP) \\
\hline - power & 11 \\
\hline - irrigation & 8 \\
\hline - municipal water & 10 \\
\hline - roads & 16 \\
\hline
\end{tabular}

Source: World Bank - expert estimates. 

Chapter 5

\section{FinANCINg OF Hidden DEFICIT AND THE UltimATE RECIPIENTS OF QUASI-FISCAL SUBSIDIES}

\footnotetext{
This chapter is aimed at estimating both the level and the structure of quasi-fiscal subsidies in the Armenian economy and analyzing the sources of their financing.
}

Our estimates for various quasi-fiscal subsidy flows in the Armenian economy are based on the analysis of non-payments between the principal economic actors involved in consumption of energy and utility services. Our main assumption here is to consider the annual increase of payables of actor $\mathrm{A}$ to actor $\mathrm{B}$ as being equal to an annual subsidy from $\mathrm{B}$ to $\mathrm{A}$. This approach has been used in a number of other recent studies (Petri et al. 2002; Pinto et al. 2000 a,b).

We reviewed the dynamics of payables and receivables for all main institutional actors for each year, 1997-2001, using the flows-of-funds framework. Table 16 provides quite a typical picture of annual inter-sectoral subsidization flows associated with non-payments for delivered energy and utility services. Many sectors were simultaneously recipients (as reflected in columns of Table 16) and providers (reflected in the rows) of quasi-fiscal subsidies.

The gas sector has been a major source of net quasi-fiscal subsidies in the economy during the entire period. From the gas industry, subsidies have been diverted to power and heating companies, while the power sector channeled most of them further to irrigation, water, and industry. Finally, all major sectors such as power, water, irrigation, and heating were involved in subsidization of households (Figure 9). In order to finance these QF subsidies and their own inefficiencies, all these sectors received explicit and implicit budget support as described above in Chapter 4 .

Therefore, the various sectors of the Armenian economy may be grouped as follows:

Main donors: providers of QF subsidies in the energy sector.

Intermediaries: sectors (drinking water and irrigation) that receive both budget and quasibudget subsidies but transfer most of them to the final recipients. 


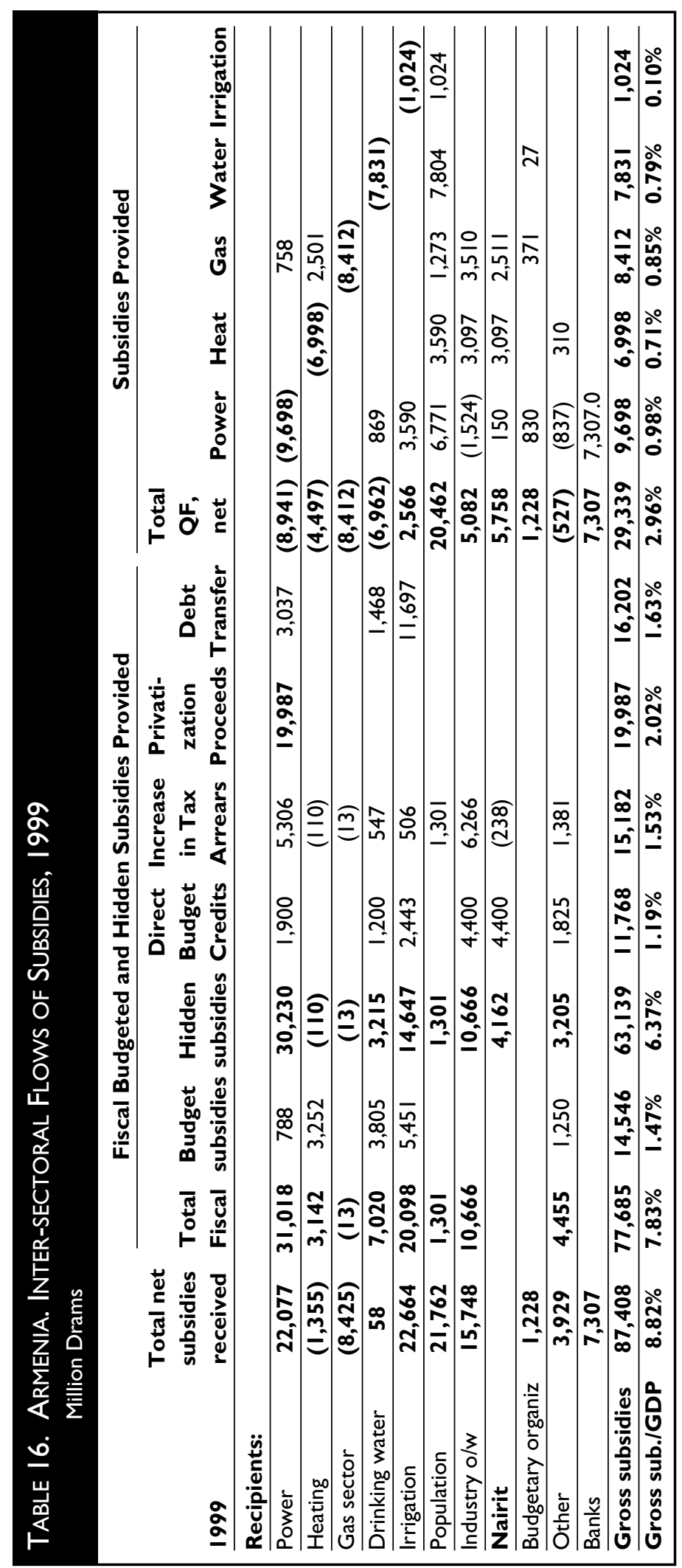




\section{Figure II. Main Subsidization Flows Through Non-Payments}

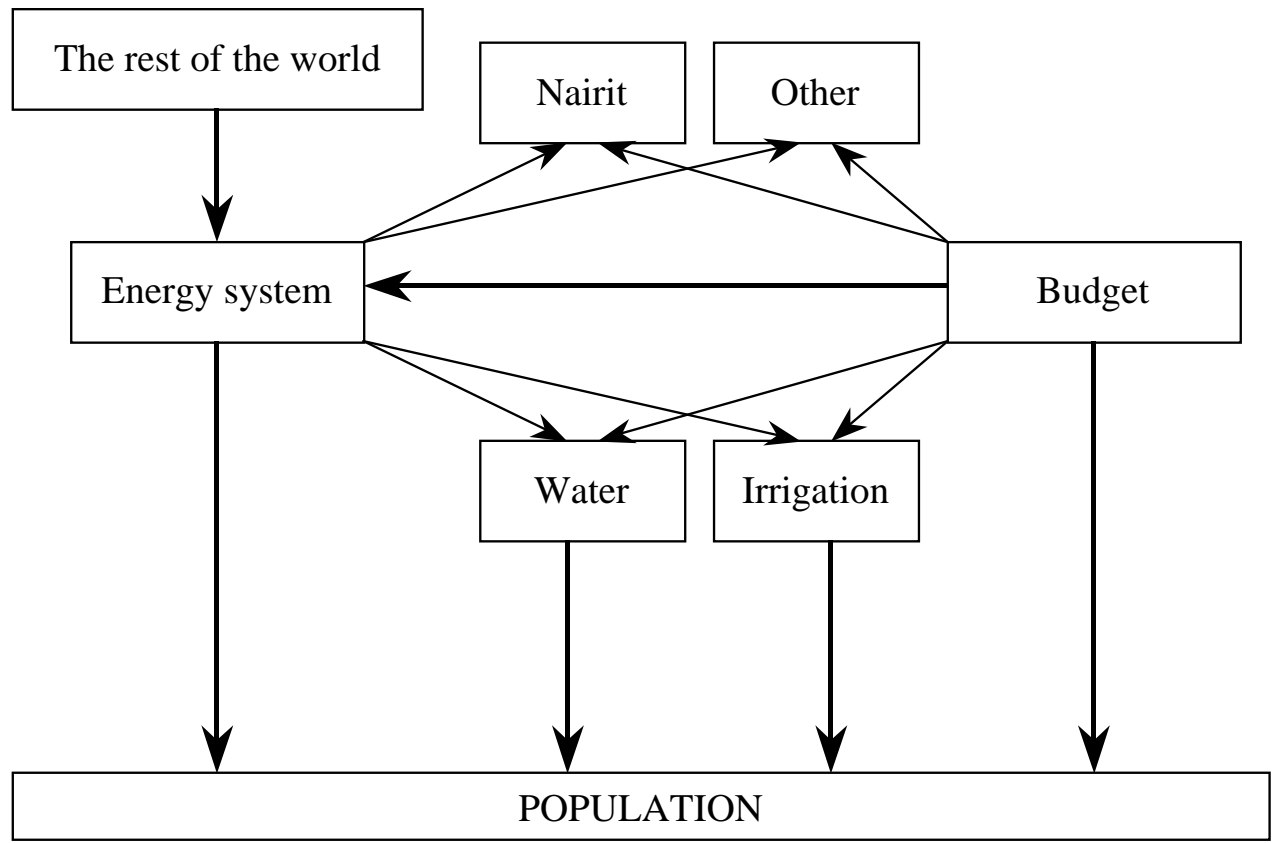

Final recipients of quasi-fiscal and budget subsidies: households and the enterprise sector.

Minor recipients of subsidies: transport, publishing.

Table 17 provides the summary estimates for annual quasi-fiscal subsidies and their allocation among major recipients. This summary is based on the consolidation of six annual tables of subsidy flows similar to Table $16 .^{28}$ It reveals that, due to a considerable reform effort, the incidence of total quasi-fiscal subsidies declined from an average of 3.8 percent of GDP in 1996-98 to 2.7 in 1999 and 1.3 in $2001 .^{29}$ This was one of the primary factors that contributed to a decline in the hidden deficit and overall improvements in fiscal performance. Table 18 provides a summary of subsidy recipients for all subsidies (that is, budgeted, hidden, and quasi-fiscal).

Figure 12 illustrates the allocation of QF subsidies among the main recipients. Figure $13 \mathrm{com}$ pares the contributions of various parts of the $\mathrm{E} \& \mathrm{U}$ sector in financing gross QF subsidies.

\section{Quasi-fiscal Subsidies to the Ultimate Users-Population and Industry}

As was shown before, the household sector is a major recipient of net quasi-fiscal subsidies, getting on average about 70 percent of the total (Figure 14). In every year from 1996-99, the population received more than 2 percent of GDP in QF subsidies, while this amount declined to about 1 per-

28. Annex B presents the full set of annual tables similar to Table 16.

29. This should be viewed in a cross-country perspective. For instance, in Russia, heavy hidden and untargeted subsidies, provided through a system of tax and energy non-payments, amounted to 7-10 percent of GDP annually in 1995-97. Adding explicit budgetary subsidies brought the total to in excess of 15 percent of GDP a year. It is not surprising that such softness of budget constraints stifled enterprise restructuring and growth and made a major contribution to the 1998 crisis through accumulation of public debts (Pinto et al. 2000a). 


\begin{tabular}{|c|c|c|c|c|c|c|}
\hline & 1996 & 1997 & 1998 & 1999 & 2000 & 2001 \\
\hline Population & $2.43 \%$ & $2.05 \%$ & $2.67 \%$ & $2.06 \%$ & $1.31 \%$ & $1.05 \%$ \\
\hline Energy & $-3.28 \%$ & $-3.83 \%$ & $-4.02 \%$ & $-2.20 \%$ & $-1.95 \%$ & $-1.34 \%$ \\
\hline Water & $-0.42 \%$ & $-0.33 \%$ & $-0.47 \%$ & $-0.70 \%$ & $-0.30 \%$ & $-0.19 \%$ \\
\hline Irrigation & $0.10 \%$ & $0.31 \%$ & $0.50 \%$ & $0.26 \%$ & $0.32 \%$ & $0.19 \%$ \\
\hline Industry & $0.62 \%$ & $1.18 \%$ & $0.86 \%$ & $0.51 \%$ & $0.29 \%$ & $0.27 \%$ \\
\hline Others & $0.55 \%$ & $0.63 \%$ & $0.46 \%$ & $0.07 \%$ & $0.33 \%$ & $0.02 \%$ \\
\hline Total & $3.70 \%$ & $4.17 \%$ & $4.50 \%$ & $2.91 \%$ & $2.25 \%$ & $1.54 \%$ \\
\hline
\end{tabular}

Source: Annex B.

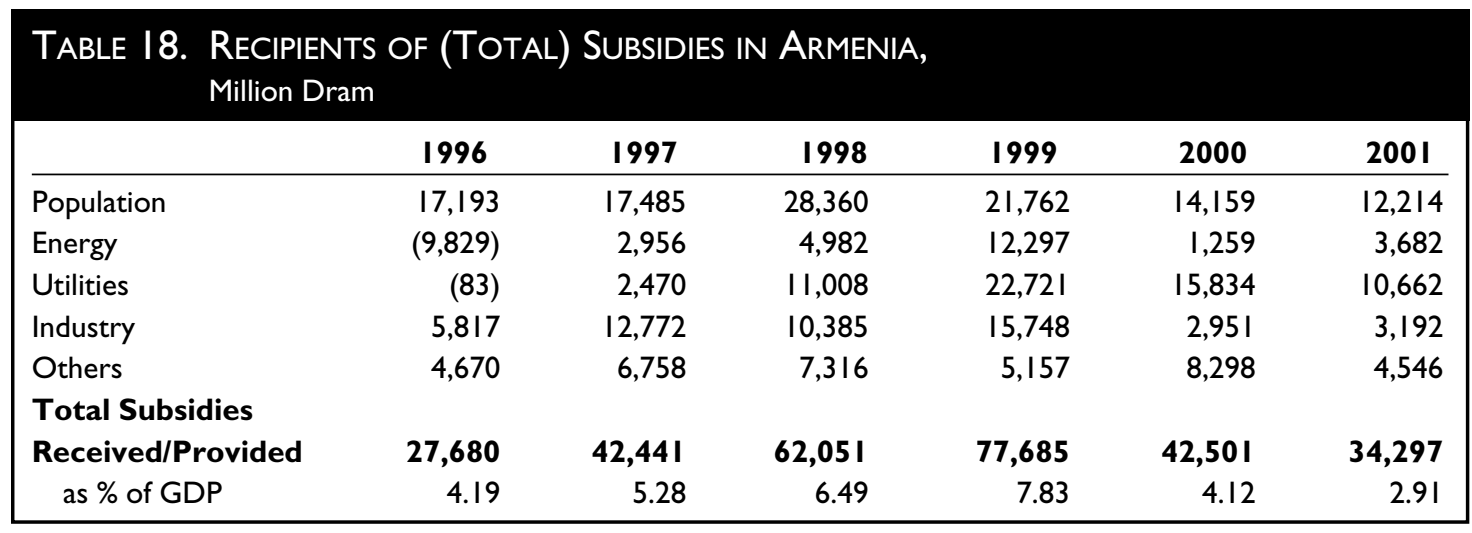

\section{FIGURE I2. QUASI-FISCAL SUBSIDIES BY RECIPIENT} Percent

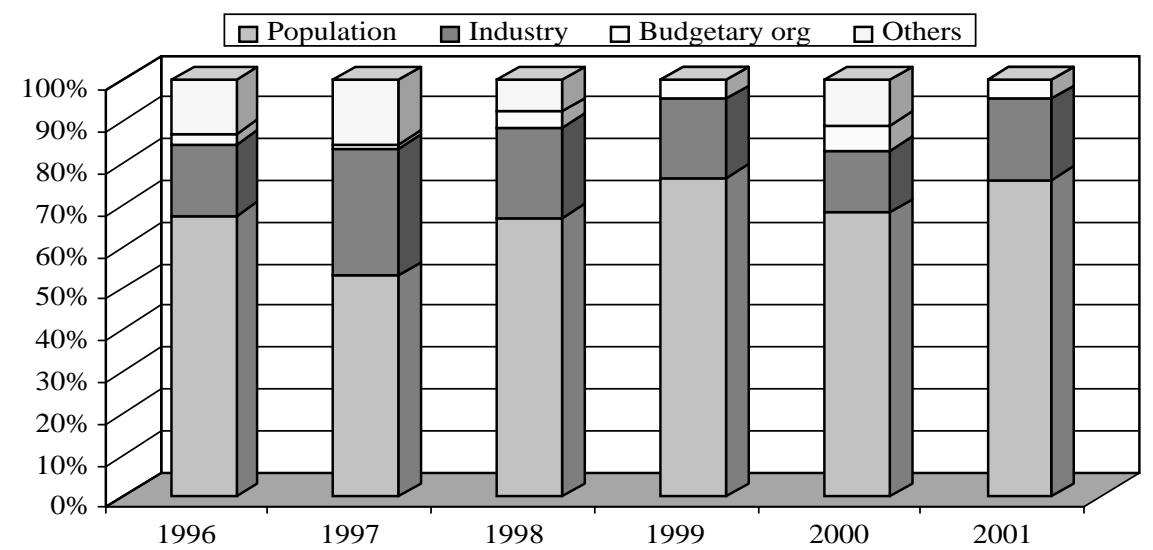




\section{FIGURE 13. QUASI-FISCAL SUBSIDIES BY SOURCE OF FINANCING, as Percent of GDP}

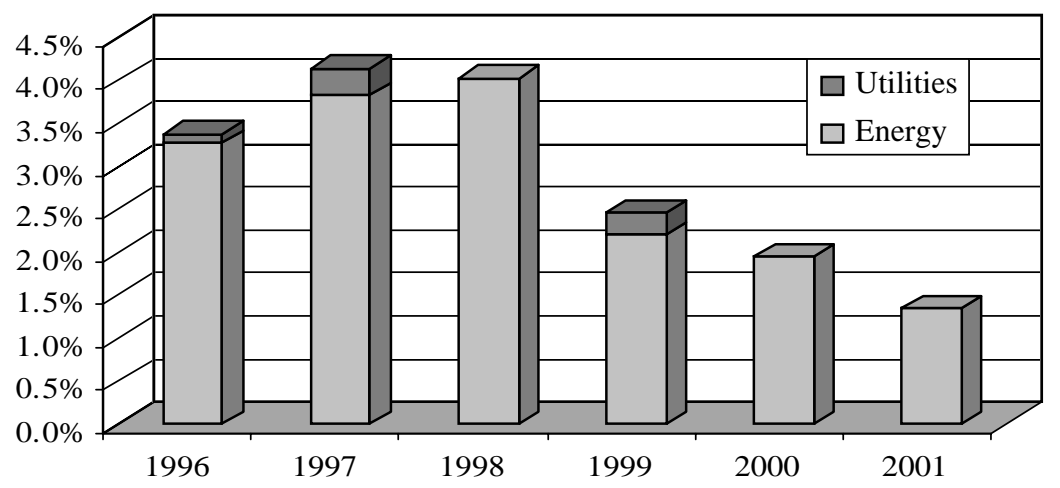

\section{Figure 14. Quasi-Fiscal Subsidies to Population as a Share of Total QFS}

\section{Percent}

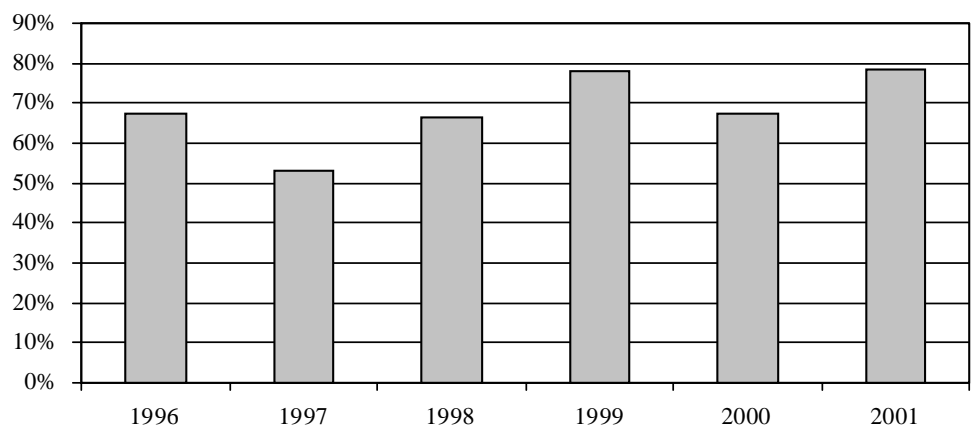

cent of GDP in 2001. These amounts include household payables to the energy, water, heat, and gas sectors as well as some (small) increases in land tax arrears. Overdue payables to the power and water sectors constitute around 70 percent of the total quasi-fiscal subsidies received by the population. In addition, in 1997-98, households received tariff subsidies, which could be roughly estimated as 1 percent of GDP.

While this level of subsidization may provide some short-term benefits to the population, its longer-term implications are quite negative. In the long run, the population is affected by poor quality and shortages of energy and water supply and an overall decline in living standards. Quasi-fiscal subsidies are also inefficient as an instrument of Government social policy: better-off households, which consume more E\&U services, receive more benefits from subsidization. ${ }^{30}$

Figure 15 compares the amount of quasi-fiscal subsidies received by the population, with the volume of public cash expenditures on social assistance and social insurance (pensions, poverty benefits and similar programs). Quasi-fiscal subsidies to the population amounted to $40-55$ percent of social public expenditures in 1996-99, but declined to $20-25$ percent in

30. See for example, World Bank (1999a) for analysis of allocation of QF subsidies in irrigation. 


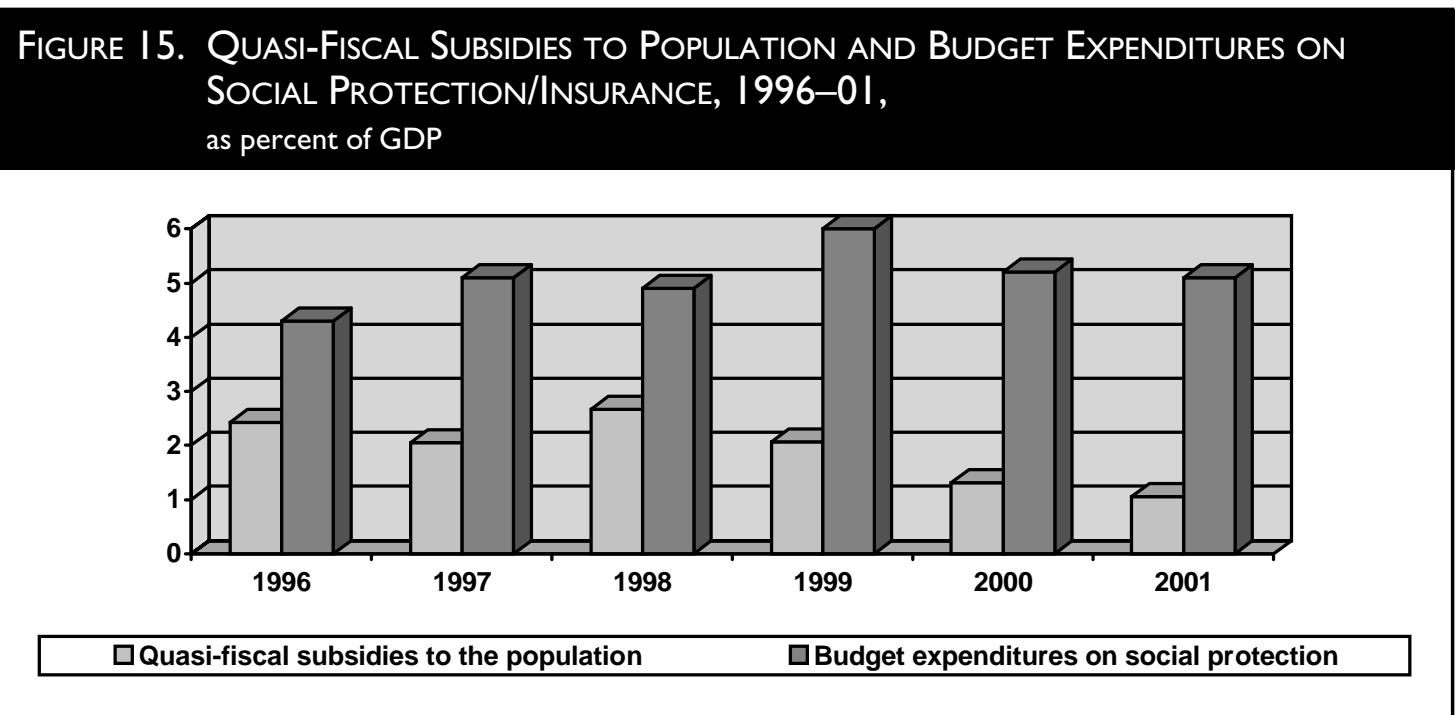

2000-2001. This is still a very high share. A further reduction in QF subsidies with a simultaneous increase in cash spending on social programs is fully justifiable in this situation. It is also worth mentioning that a significant increase of 1 percent of GDP in Government social cash spending between 1997 and 2001 provided only a compensation for a simultaneous withdrawal of quasi-fiscal subsidies of the same magnitude. Overall, the population has not gained much. ${ }^{31}$

The enterprise sector (outside of the E\&U sector) has been the second largest recipient of QF subsidies. Commercial enterprises received more than 1 percent of GDP in total QF subsidies in 1997, about 0.5 in 1999, and less than 0.3 in 2000-01 (Table 17). In all years except 1999, QF subsidies were the main source of subsidization for the enterprise sector (Figure 16).

\section{Figure I6. Budgeted, Hidden, ANd QUASI-FISCAL Subsidies to the ENTERPRISE SeCtor, as percent of GDP}

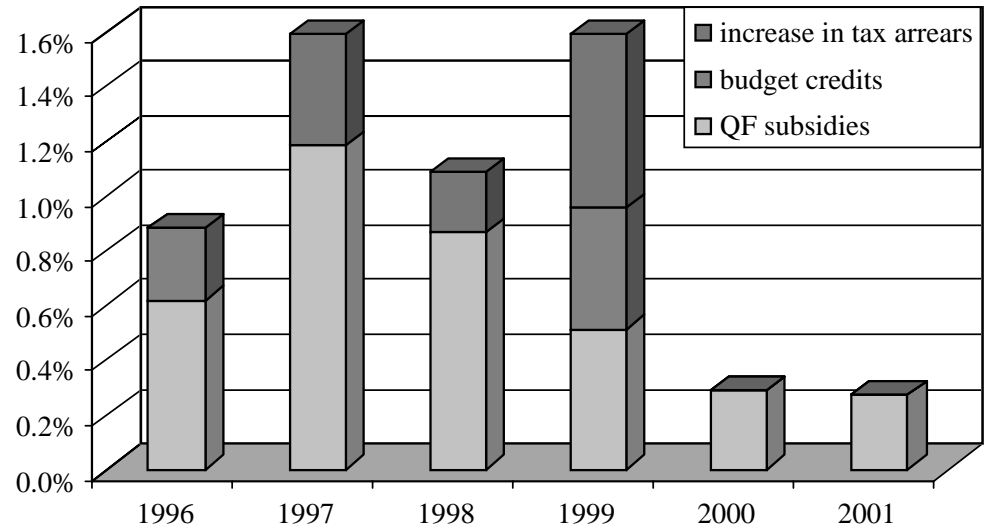

31. However, significant efficiency gains have been achieved because Government social programs are better targeted to support the poor compared to QF subsidies. 
Enterprise subsidies are heavily concentrated. Nairit, a major chemical plant, was the only industrial enterprise that remained a recipient of direct budget subsidies in the late 1990s. Nairit was considered by the authorities to be too large to fail. The total average annual subsidies (explicit and implicit) received by Nairit in 1997-2000 amounted to 0.6 percent of GDP (World Bank 2001c). In dollar equivalent, every one of the 4000 employees was a recipient of an annual subsidy that amounted to about $\$ 2,500$. This should be compared to an average industrial wage of about $\$ 600$ a year in that period, and the average salary of a teacher of $\$ 350$ a year. The Government completed privatization of Nairit in the first part of 2002.

The Government should accelerate liquidation and/or forced restructuring of such large nonviable firms, which would have a beneficial impact on the entire enterprise sector. However, there is no evidence so far that softness of budget constraints for a few of the largest companies was among the major factors that slowed down the overall enterprise restructuring process. Hidden and quasi-fiscal subsidies in Armenia have been much more a fiscal and social policy issue than a restructuring problem.

\section{How E\&U Companies Have Financed QF Subsidies-The Case of the Power Sector}

The main source of funding of quasi-fiscal subsidies was the operational cash flow of (mostly publicly-owned) energy companies - primarily in the gas and power sectors. In turn, gas and power companies financed their operational deficit from three sources: (a) by building debts to their suppliers and commercial banks; (b) through under-maintenance of company assets; and (c) getting a considerable amount of explicit and implicit budget assistance.

Table 19 presents an illustration of how quasi-fiscal subsidies have been financed by the energy sector. It shows that the ultimate source of financing of QF subsidies, provided by the consolidated energy sector (gas, power and heating sub-sectors), was the Government budget. Since 1997, each year except 2000, the total subsidies received by the energy sector have been higher than provided by it to the rest of the economy. As one could expect, the Government was not able to shift the responsibility for public support to the population and ailing industries outside of the budget. Additional public resources were consumed by the power sector to cover its inefficiencies and internal losses, including stealing.

\begin{tabular}{|c|c|c|c|c|c|c|}
\hline & 1996 & 1997 & 1998 & 1999 & 2000 & 2001 \\
\hline QF Subsidies provided & 3.28 & 3.83 & 4.02 & 2.20 & 1.95 & 1.34 \\
\hline Subsidies received, o/w & 1.79 & 4.20 & 4.54 & 3.44 & 2.07 & 1.66 \\
\hline Budgeted & 0.00 & 0.11 & 0.02 & 0.41 & 0.01 & 0.01 \\
\hline Hidden & 1.79 & 4.09 & 4.52 & 3.04 & 2.06 & 1.64 \\
\hline Net: (+)Provided/(-)Received & 1.49 & -0.37 & -0.52 & -1.24 & -0.12 & -0.310 \\
\hline Memo: Underfinancing & 0.5 & 0.5 & 0.5 & 0.5 & 0.5 & 0.5 \\
\hline
\end{tabular}



Chapter 6

\section{Main Policy Conclusions}

The reduction in quasi-fiscal deficits has been a major source of fiscal adjustment in Armenia in the second part of the 1990s; this reduction, as well as decline in the hidden deficit, may be seen as an indication that the recent fiscal stabilization was quite genuine. That is, an improvement in budget performance has not been accompanied by accumulation of any significant Government off-budget liabilities.

These declines in quasi-fiscal deficits also explain significant improvements in macroeconomic stability in Armenia (since 1997) and positive changes in its debt profile (since 2000).

Improved performance in the energy sector (primarily in power and gas) was directly associated with the decline in incidence of quasi-fiscal subsidies.

Still, the current level of public sector deficit remains too high, which requires an additional adjustment effort; as recent research suggests (World Bank 2002), further adjustment should prioritize an improvement in tax performance, not additional expenditure compression.

To make fiscal adjustment sustainable a further strengthening of financial control, accounting and reporting in the public sector is needed, including through better Government monitoring of debts and other liabilities accumulated by the large state enterprises and phasing out the phenomenon of implicit (hidden subsidies), such as debt-for-equity swaps.

The population has been the major recipient of quasi-fiscal subsidies in Armenia; this means that in addition to its negative impact on fiscal performance, quasi-fiscal subsidization has been distorting the Government's social policies; at the same time, these subsidies had less impact on enterprise restructuring.

Recent significant compression in quasi-fiscal subsidies to population provides an additional argument in favor of expansion in Government social spending, especially on poverty benefits and old age pensions.

The proposed approach to the analysis of quasi-fiscal deficits and subsidies, based on estimates of accumulated debts in the public sector and its main parts, seems to be fully applicable to other economies in transition, especially to those low-income CIS countries, which are heavily dependent on energy imports. 

Annex A

\section{EXTERNAL BORROWING BY THE GOVERNMENT TO SUPPORT OPERATIONS OF THE ENERGY AND UTILITY SECTOR}




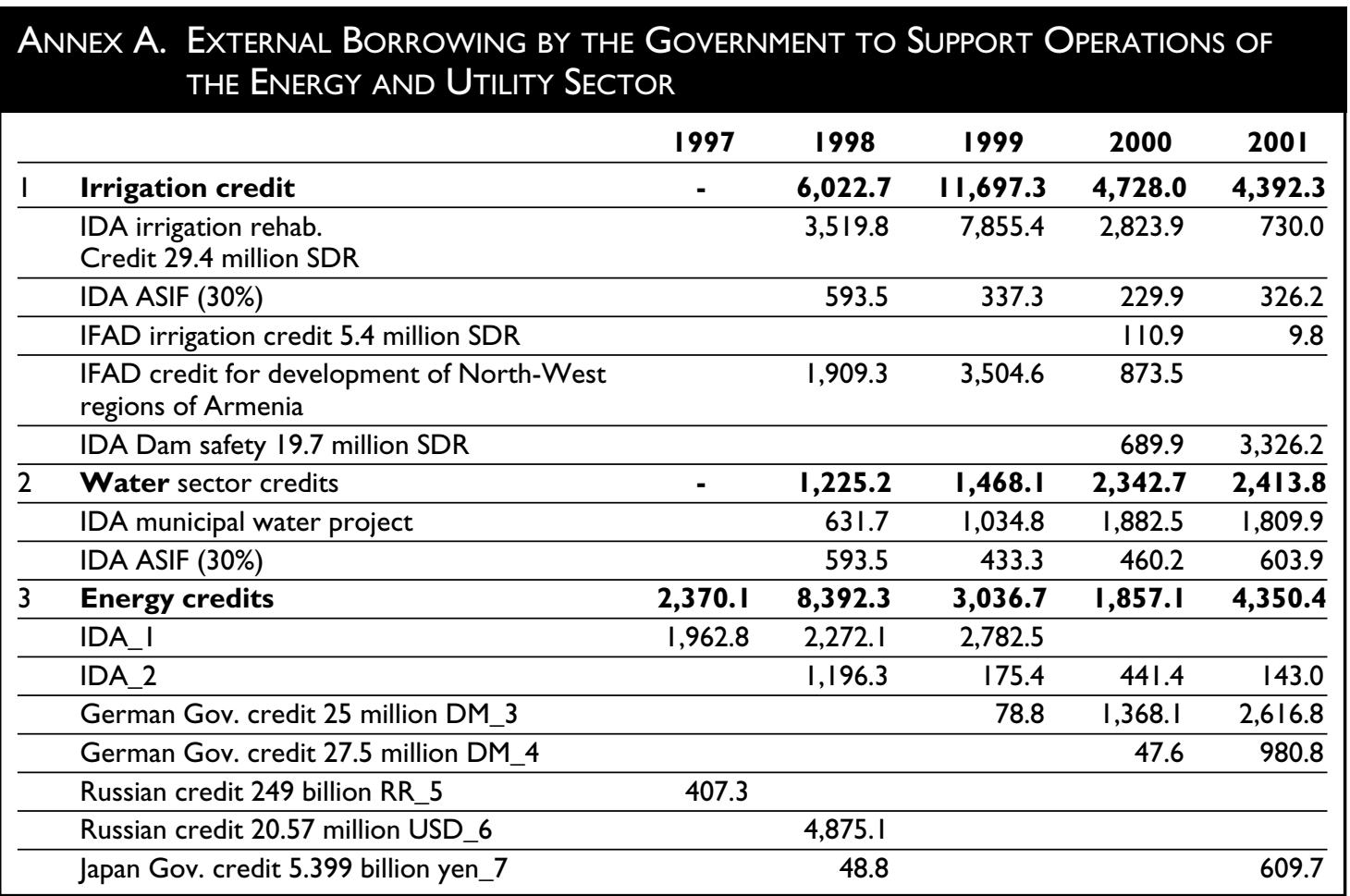

\section{Energy credit}

I Energy sector maintenance credit 9.4 million SDR

Energy Transmission and distribution credit 15 million

2 SDR

3 for repair of Kanaker HES

4 for installation of electricity transmission systems

5 for Nuclear fuel

6 for Nuclear Fuel

7 for rehabilitation the electricity transmission and distribution systems 
Annex B

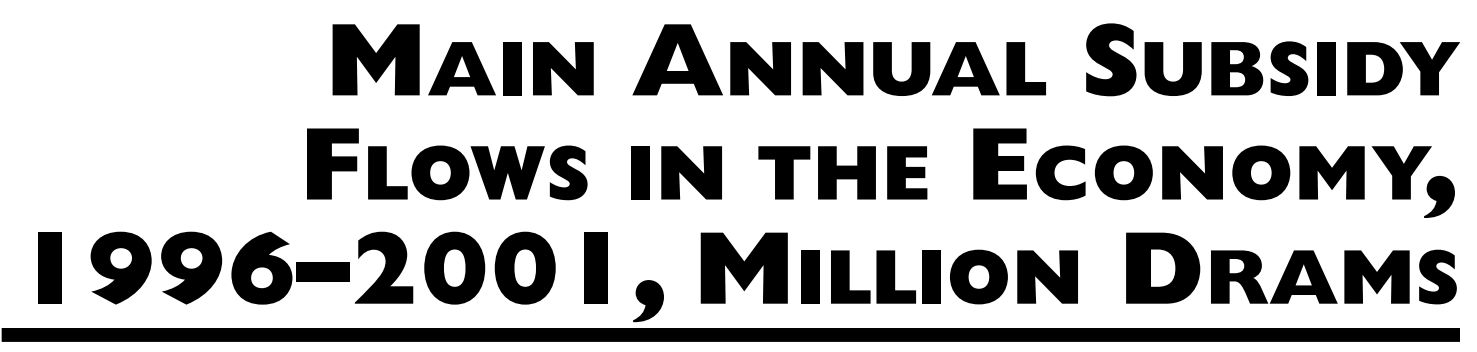




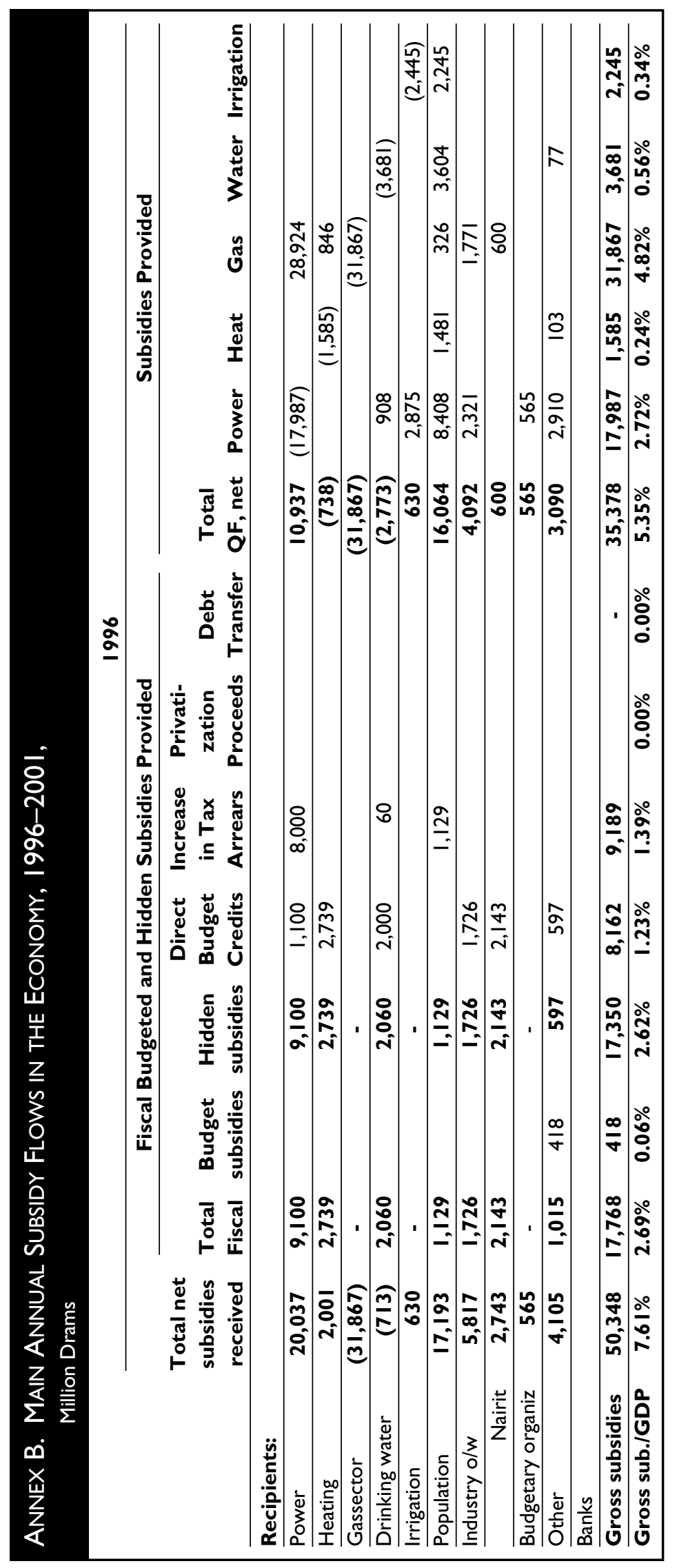




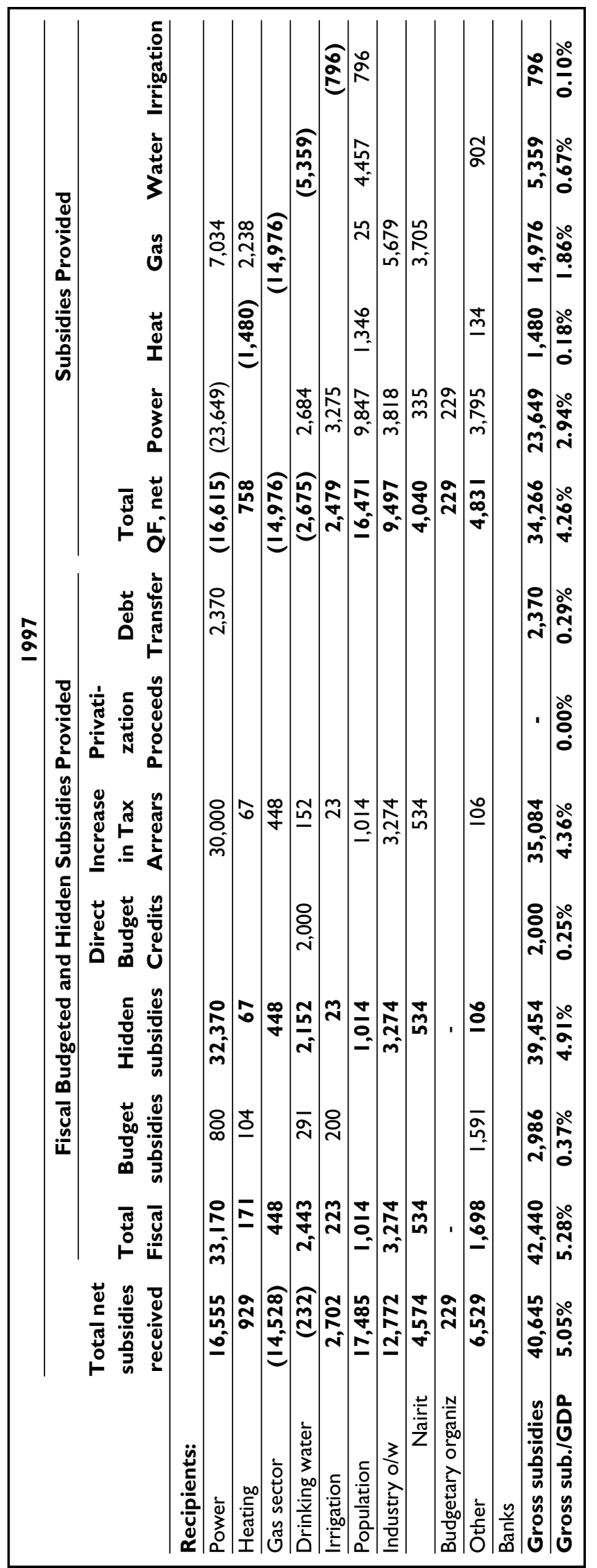




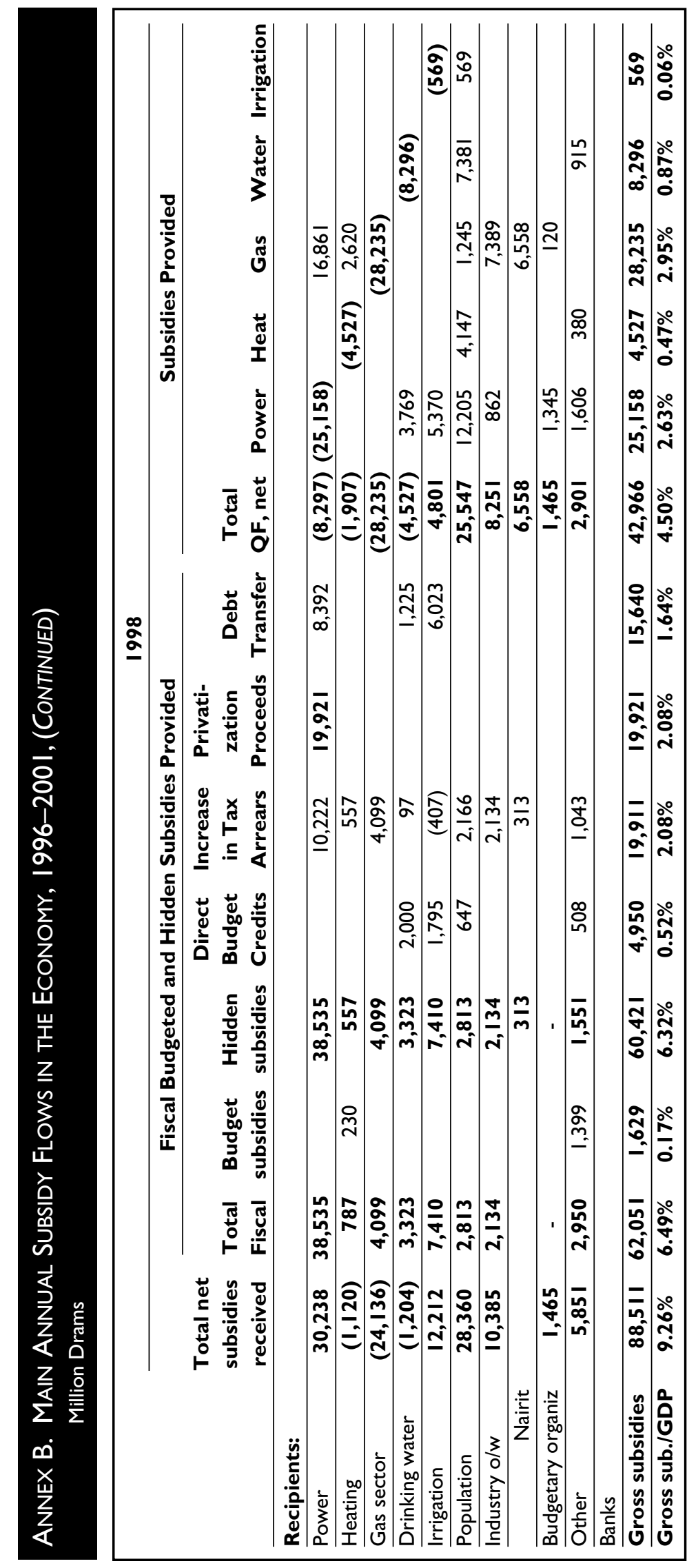




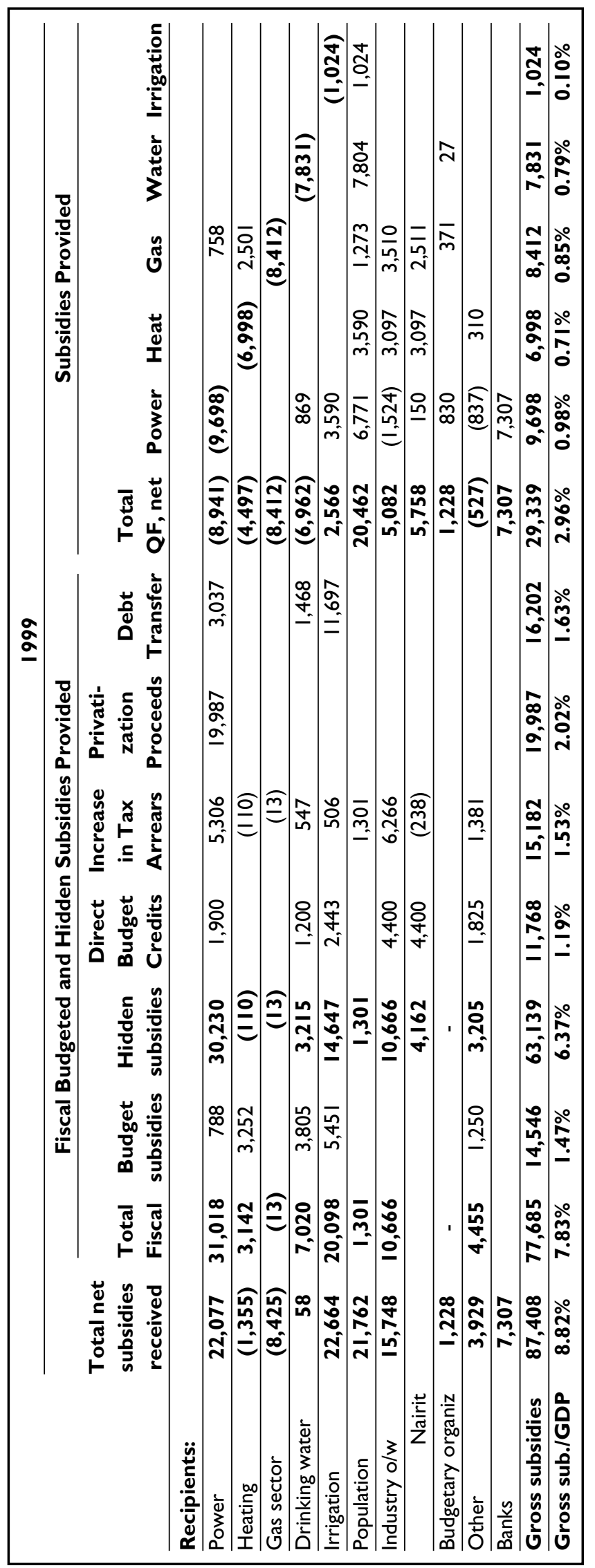




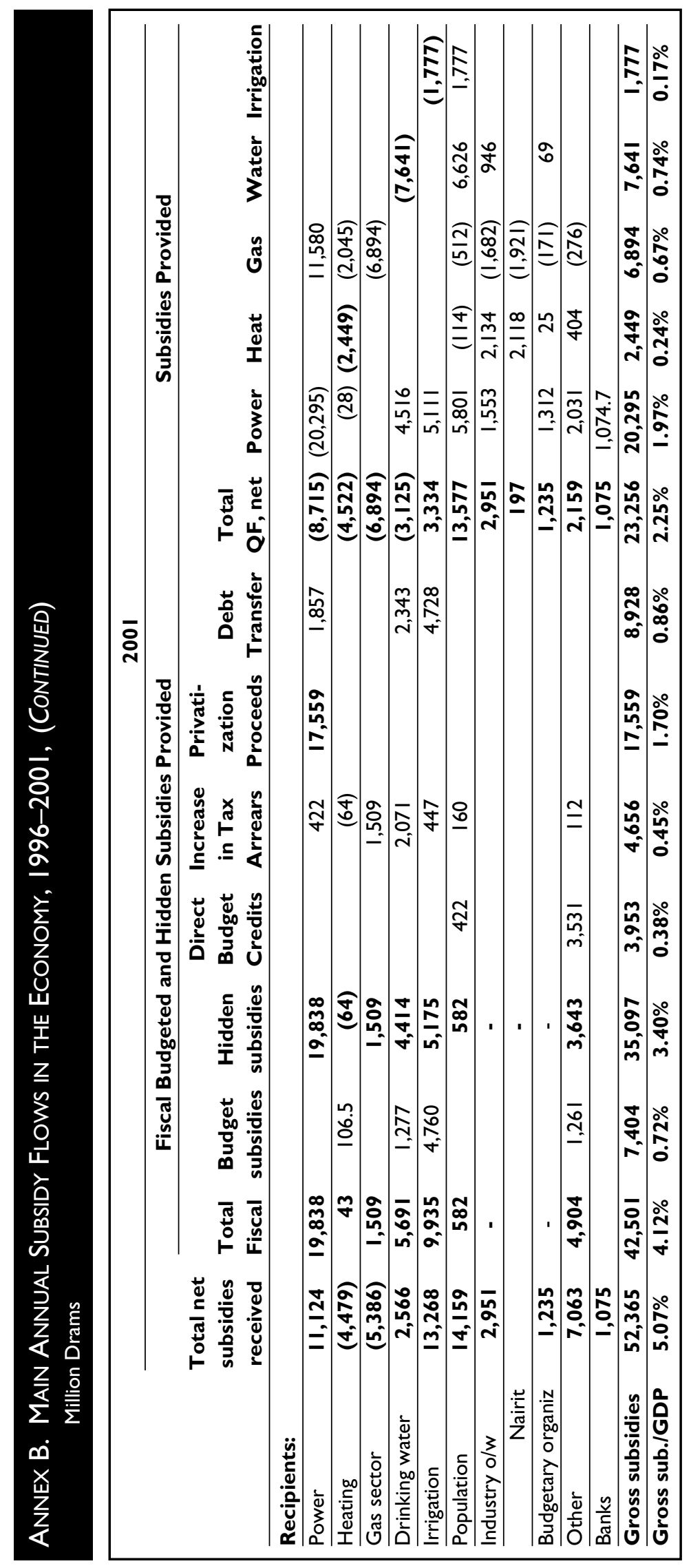




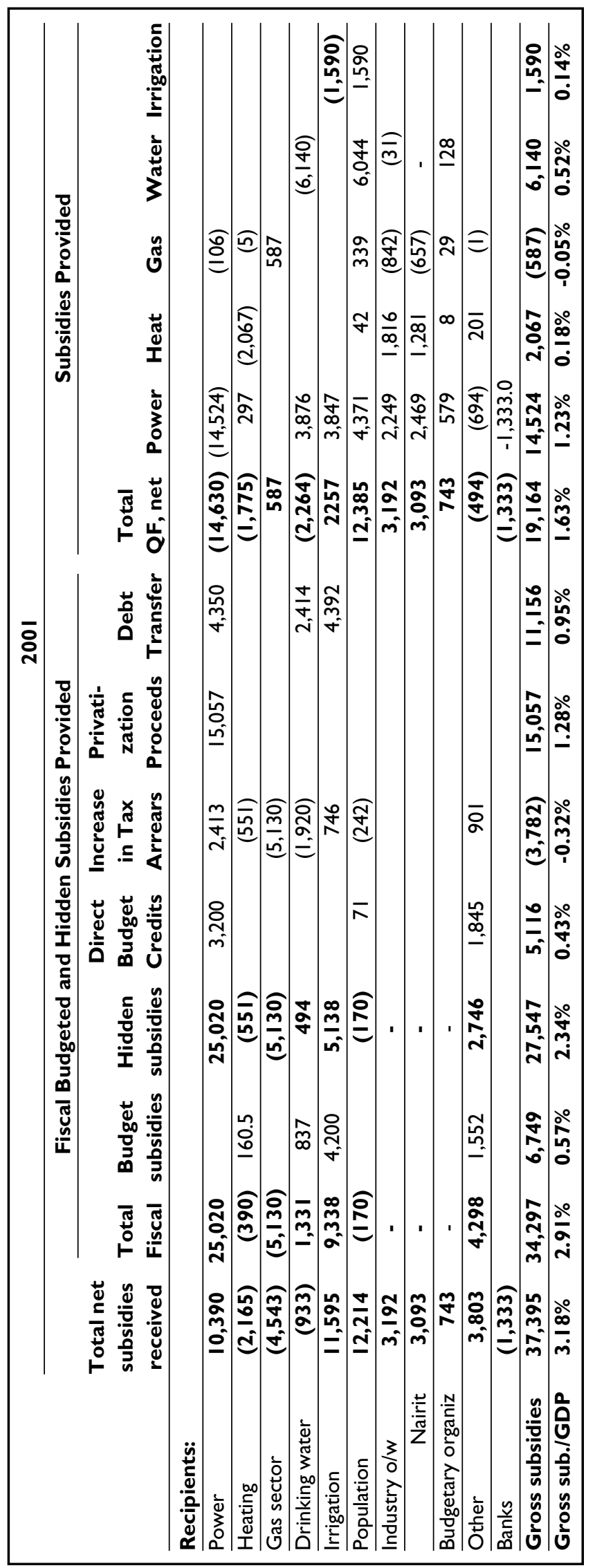





\section{REFERENCES}

Alam, Asad and Mark Sundberg. 2002. A Decade of Fiscal Transition. Policy Research Working Paper No. 2835. Washington D.C.: World Bank.

Delyagin, Michael and Lev Freinkman. 1993. "Extrabudgetary Funds in Russian Public Finance." RFE/RL Research Report 2(48).

Easterly, William. 1999. "When is Fiscal Adjustment an Illusion?" Economic Policy 28 (April):57-86.

Easterly, William and Paulo Viera Da Cunha. 1993. Financing the Storm. Macroeconomic Crisis in Russia, 1992-93. Policy Research Working Paper No 1240. Washington D.C.: World Bank.

Freinkman, Lev and Irina Starodubrovskaya. 1996. "Restructuring of Enterprise Social Assets in Russia: Trends, Problems, Possible Solutions.” Communist Economies \& Economic Transformation 8(4):437-469.

Gaddy, Clifford G. and Barry W. Ickes. 1998. "Russia’s Virtual Economy.” Foreign Affairs 77(5):53-67.

Horvath, Balazs, Nita Thacker, and Jiming Ha. 1998. "Achieving Stabilization in Armenia.” IMF Working Paper WP-98/38 (March). Washington, D.C.: IMF.

International Monetary Fund. 1995. Guidelines for Fiscal Adjustment. Pamphlet Series No. 49.

IMF Fiscal Affairs Department, Washington, D.C.

- 2001. Manual on Fiscal Transparency. Washington, D.C.

Kharas, Homi and Deepak Mishra. 2001. "Fiscal Policy, Hidden Deficit, and Currency Crises." World Bank Economists' Forum: 31-48.

PADCO. 2001. Financial and Actuarial Analysis of the Armenian Pension System. Armenia Social Transition Program by the USAID. Report No. 35 (March 19). Yerevan.

Polackova-Brixi, Hana, Hafez Ghanem, and Roumeen Islam. 2001. "Fiscal Adjustment and Contingent Liabilities: Case Studies of the Czech Republic and the Former Yugoslav Republic of Macedonia." World Bank Economists' Forum: 49-77. 
Polachkova Brixi, Hanna and Allen Schick, eds. 2002. Government at Risk. Contingent Liabilities and Fiscal Risk. Oxford University Press and the World Bank.

Polachkova Brixi, Hanna, Allen Schick and Leila Zlaoui. 2002. The Challenges of Fiscal Risk in Transition: Czech Republic, Hungary and Bulgaria. In Polachkova Brixi, and Schick, eds., Government at Risk, World Bank.

Pinto, Brian, Vladimir Drebentsov, and Alexander Morozov. 2000a. Dismantling Russia's

Nonpayments System. Creating Conditions for Growth. World Bank Technical Paper No. 471, Washington, D.C.: World Bank.

Pinto, Brian, Vladimir Drebentsov, and Alexander Morozov. 2000b. "Give Growth and Macroeconomic Stability in Russia a Chance: Harden Budgets by Eliminating Non-Payments." The Economics of Transition 8(2):297-324.

Petri, Martin, Gunther Taube and Aleh Tsyvinski. 2002. Energy Sector Quasi-Fiscal Activities in the Countries of the Former Soviet Union. IMF Working Paper, WP/02/60.

Selowsky Marcelo. 1998. "Fiscal Deficit and Quality of Fiscal Adjustment." In The Challenges for Public Liability Management in Central Europe. Washington, DC.: World Bank.

Tanzi, Vitto and George Tsibouris. 1999. "Fiscal Reform over Ten Years of Transition.” Paper presented to the Fifth Dubrovnik Conference on Transition Economies, July 23-25.

World Bank. 1999a. Armenia's Private Agriculture: 1998 Survey of Family Farms. Washington D.C.

- 1999b. Non-payments in the Electricity Sector in Eastern Europe and the Former Soviet Union. World Bank Technical Paper No. 423. Washington D.C.

- 2001a. Armenia, Georgia, Kyrgyz Republic, Moldova, and Tajikistan: External Debt and Fiscal Sustainability. Board Paper. Washington D.C.

- 2001b. Kyrgyz Republic. Fiscal Sustainability Study. Washington D.C.

. 2001c. Armenia: Growth Challenges and Government Policies. Report No. 22854-AM

(in two volumes). Washington D.C.

- 2002. Armenia: Public Expenditure Review. Washington D.C. 